IZA DP No. 5670

Crime, Prosecutors, and the Certainty of Conviction

Horst Entorf

April 2011 


\title{
Crime, Prosecutors, and the Certainty of Conviction
}

\author{
Horst Entorf \\ Goethe University Frankfurt \\ and IZA
}

\section{Discussion Paper No. 5670 \\ April 2011}

IZA

P.O. Box 7240

53072 Bonn

Germany

Phone: +49-228-3894-0

Fax: +49-228-3894-180

E-mail: iza@iza.org

Any opinions expressed here are those of the author(s) and not those of IZA. Research published in this series may include views on policy, but the institute itself takes no institutional policy positions.

The Institute for the Study of Labor (IZA) in Bonn is a local and virtual international research center and a place of communication between science, politics and business. IZA is an independent nonprofit organization supported by Deutsche Post Foundation. The center is associated with the University of Bonn and offers a stimulating research environment through its international network, workshops and conferences, data service, project support, research visits and doctoral program. IZA engages in (i) original and internationally competitive research in all fields of labor economics, (ii) development of policy concepts, and (iii) dissemination of research results and concepts to the interested public.

IZA Discussion Papers often represent preliminary work and are circulated to encourage discussion. Citation of such a paper should account for its provisional character. A revised version may be available directly from the author. 
IZA Discussion Paper No. 5670

April 2011

\section{ABSTRACT \\ Crime, Prosecutors, and the Certainty of Conviction ${ }^{1}$}

This paper tests predictions of a structural, augmented supply-of-offenders model regarding the relative effects of police, public prosecution and courts, respectively, on crime. Using detailed data on the different stages of the criminal prosecution process in Germany, empirical evidence suggests that public prosecutors and their influence on the probability of conviction play a major role in explaining the variation of crime rates, while the impact of the severity of punishment is small and insignificant.

JEL Classification: K14, K41, C23

Keywords: general deterrence, certainty of punishment, public prosecutors, informal punishment, panel data

Corresponding author:

Horst Entorf

Goethe University Frankfurt

Department of Economics and Business Administration

Grüneburgplatz 1

D-60323 Frankfurt

Germany

E-mail: entorf@wiwi.uni-frankfurt.de

\footnotetext{
${ }^{1}$ I am grateful to Michael Burda, Christoph Engel, Gil Epstein, Martin Hellwig, Jan van Ours, John de New, Christoph Schmidt, Christian Traxler, Ben Vollaard, and seminar participants at the MPI Bonn, the University of Tilburg, the IZA conference on the Economics of Risky Behavior in Washington D.C., the RWI Essen and the $1^{\text {st }}$ Bonn \& Paris Meeting on Law and Economics in Paris for useful discussions. I would also like to thank Birgit Herrmann for helpful comments on an earlier version of the paper.
} 


\section{Introduction}

Neither police nor judges seem to play the leading role in the investigation and the criminal decision process. Prior to judicial decisions, a growing share of cases has already been discharged by the public prosecutor. In both the U.S. and European legal systems, the crucial discretionary power of the prosecutor is to determine which case should be disposed of before trial by either dismissal of the charges or by imposing certain obligations on suspects in exchange for laying the file aside. Such practices are known as pre-trial diversion or informal sanctions. In Germany, the portion of crime suspects formally convicted in a court (under general and juvenile penal law) compared to all people sanctioned (informally and formally) steadily declined from 64\% in 1981 to 42\% in 2008 (Heinz, 2010, p.50). The prosecutor accounts for the bulk of all cases, the judges in courts are only responsible for $14.5 \%$ of all dismissals. ${ }^{2}$ Criminal policy in the U.S. followed a quite different path. Whereas Western European countries such as Germany adopted policies of diversion and non-custodial sentences, in the U.S., as a response to increased severity of sanctions (see Raphael and Stoll, 2009), the incarceration rate of the state prison populations grew at an unprecedented rate, nearly quadrupling between the mid 1970s and the present, and reached the unprecedented number of 756 prisoners per 100,000 of the national population in 2006 (see Walmsley, 2009). However, the crucial question is whether the benefits from smaller imprisonment rates have been offset by higher costs of crime in response to decreasing general deterrence. A look at German data reveals that at least German violent crime rates show a continuous upward trend and have more than doubled since the beginning of the 1970s (GESIS, 2007).

To fully understand the impact of criminal policies in the U.S., Germany and elsewhere, the role of key players and their decisions, i.e. interactions of police, prosecutors and courts representing the law enforcement system (Van Tulder and Van der Torre, 1999) have to be taken into account. Many studies only rely on the probability of detection, i.e. on the role of police, when discussing the role of 'expected' sanctions. Other studies, in particular articles dealing with U.S. data and thus motivated by the highly persistent upward trend in prisoner population, focus on the imprisonment rate and the severity of sanctions as crucial factors of deterrence (see the survey by Donohue, 2009). Only few studies also cover the risk of convictions, e.g. by the ratio of convictions to arrests. Among these exceptions are the early papers by Sjoquist (1973), Carr-Hill and Stern (1973), and Wolpin (1978) based on regional

\footnotetext{
${ }^{2}$ In 2008, the number of dismissals performed by German prosecutors was 1.006 Mio, compared to 0.886 Mio convictions and 0.170 Mio acquittals in courts (Heinz, 2010, p. 49).
} 
cross-sectional data. Cornwell and Trumbull (1994, their approach was replicated by Baltagi, 2006), who also were among the first authors who applied panel econometrics, presented exceptional work because of their comprehensive list of law enforcement variables containing the probabilities of arrest, conviction (conditional on arrest), and imprisonment (conditional on conviction) as well as the severity of sanctions. However, the general impression is that only few studies have taken account of all factors, something that was also pointed out by Mustard (2003) as well as Mendes and McDonald (2001). In particular the interplay of conviction rates and sentence lengths, i.e. essential components of certainty and expected severity of punishment, have been neglected. However, it is obvious that components of general deterrence do not work independently of each other. Missing factors of law enforcement might cause severe omitted variable biases. ${ }^{3}$

This paper focuses on the German experience, where in particular the steadily increasing discretionary power given to prosecutors and the vast range of potential custodial and noncustodial sanctions is of general importance. To cope with the manifold situation of all stages of the prosecution process, theoretical and econometric modeling consider the activities of the police, public prosecution and courts, i.e. the probability of being arrested by the police, the probability of being convicted conditional upon arrest, and the probabilities of being imprisoned, being fined or being on probation given conviction. As the Criminal Law Reform entailed changes away from short-term custodial sanctions, also the average length of prison sentences should be focused on when calculating the expected costs of committing a crime.

As will become clear in the course of the paper, conditional on identical clearance rates, expected sanctions strongly differ given prevailing regional (state) criminal prosecution policies. Similar to Kessler and Piehl (1998) and Lacasse and Payne (1999), the analysis focuses on the degree of discretion in the criminal justice system and it studies the impact of regional discretion on law enforcement and justice system outcomes. Unlike quoted studies, which analyze explanatory factors such as heterogeneity of social norms, this paper exploits data and information from different experiences and performances amongst coexisting and competing criminal justice policies of federal states.

\footnotetext{
${ }^{3}$ Interestingly, some meta-analysis (Dölling et al., 2009) on 391 deterrence studies using criminal statistics reveals that including the ratio of convictions to reported crimes seems to produce higher absolute t-values (median t-value of considered effect estimates= -3.5) than using the clearance rate (median t-value $=-1.8$ ), or the average length of served prison sentences (median t-value $=-0.6$ ). However, the meta-analysis does not cover the impact of interacting deterrence variables.
} 
Conclusions will be based on structural econometric evidence ${ }^{4}$ of a theoretical model which considers both formal and informal and as well as non-custodial and custodial sanctions (e.g. sentences on and without probation). The resulting augmented supply of offences is estimated using a unique database combining information from different sources of official judicial statistics covering 24 years of criminal sanctioning practices of (West) German states. It provides offence and age-specific crime rates of three major violent and four property types and maps the comprehensive system of criminal prosecution, including decisions regarding type (fine, probation, imprisonment) and extent (length of prison sentence) of punishment.

Results presented in this article suggest that crime is particularly deterred by the certainty of conviction. Here, contrary to popular belief, neither police nor judges but public prosecutors play the leading role. Extending the severity of sentences, however, does not seem to provide a suitable strategy for fighting crime. In particular, the length of the imprisonment term proves insignificant.

This paper is organized as follows. Section 2 provides a model of custodial and non-custodial sentencing. Section 3 highlights descriptive evidence showing prevailing heterogeneity of sentencing practices at the disaggregated state level in Germany. In Section 4 econometric results are presented. Section 5 concludes.

\section{Theoretical Considerations: Custodial and Non- Custodial Sentences in a Model of Crime}

In order to understand the roles of police, prosecutors and courts in empirical data and econometric estimations, in this chapter the standard model of general deterrence is extended by considering custodial and non-custodial sentences. This distinction is of importance because non-custodial sentences are usually considered less severe than unconditional custodial sentences, and because data reveal significant trends towards higher shares of noncustodial sentencing (see Chapter 3). The framework maps the cascade police/public prosecution/court/sentencing decisions with a model of time allocation. Ehrlich (1973) introduced this approach into the economics of crime. He considers an individual who allocates his fixed amount of time between legal and illegal income-generating activities. Many authors have applied and extended the model, but also questioned some of Ehrlich's

\footnotetext{
${ }^{4}$ See, among others, Heckman (2000) and Deaton (2010), and the Symposium of the Journal of Economic Perspectives, 24(2), for the importance of structural econometrics in public policy analysis.
} 
general results. Block and Heineke (1975), in particular, attacked Ehrlich's findings by showing that if the time allocated to legal and illegal activity is introduced into the utility function any comparative static result would be impossible without further assumptions.

Nevertheless, the subsequent model in the tradition of previous work of, among others, Ehrlich (1973), Block and Heineke (1975), Wolpin (1978, 1980), Witte (1980), Zhang (1997), Grogger (1998), and Funk (2004) helps to clarify ideas and summarizes theoretical predictions and conclusions. We consider an individual who maximizes his/her expected utility $\mathrm{E}(\mathrm{U})$ by allocating available time $\mathrm{T}$ to legal $\left(t_{\ell}\right)$ and illegal $\left(t_{i}\right)$ activities, w.r.t. $t_{\ell}+t_{i}<T$ (non-binding time constraint). The individual's utility and well-being emerges from her time allocated to legal work resulting in legal income $L\left(t_{\ell}\right)$, and from the time spent on illegal activities rewarded by $G\left(t_{i}\right)$. Illegal activities are detected and punished with exogenously given probability $p$. We can decompose $p \equiv p_{c l} p_{a c \mid c l} p_{c \mid a c}$, where $p_{c l}=$ probability of detection, $p_{a c \mid c l}=$ probability of trial if detected and $p_{c v \mid a c}=$ probability of conviction if brought to court, i.e. $p$ combines the discretionary work of police, it captures incentives from varying informal sanctions (through decisions of public prosecution), and it covers the fact of a conviction (conditional on indictment), but does not include the sentence itself. This decomposition is of importance for the econometric model (see below), where the respective individual roles of police, public prosecutors and judges need to be identified separately. ${ }^{5}$ In the present theoretical model, we refrain from splitting up the decision process into further ramifications such that it suffices to consider the overall effect of $p{ }^{6}$

As outlined in the Introduction, the main focus of this article is to contrast severity and certainty of sanctions through 'tough' (unconditional, 'custodial') prison sentences on the one hand, and more lenient sentencing practices, such as probation, parole and fines, henceforth defined as 'non-custodial sentences', as well as informal sanctions on the other hand.

\footnotetext{
${ }^{5}$ In the econometric model, $p$ will be decomposed into $p_{c l}$ (measured as clearance rate) and $p_{a c \mid c l} p_{c v \mid a c}$ (overall 'conviction rate'). The reason for constructing a product instead of using all variables separately lies in the rather small variance of the share of acquittals, $p_{c v \mid a c}$, over time and across states. Empirically, the variance of $p_{a c \mid c l} p_{c v \mid a c}$ is driven by $p_{a c \mid c l}$, i.e. discretionary influences of prosecutors covered by the indictment rate (see the descriptive evidence below).

${ }^{6}$ The presented model could be extended by separate treatment of all three different stages $p \equiv p_{c l} p_{a c \mid c l} p_{c v \mid a c}$ of general deterrence, but expected effects of $p$ are identical to those of all factors underlying $p$ unless standard assumptions (e.g. with respect to different legal or illegal payoffs at subsequent stages) would be changed.
} 
Following this intention, we assume that the convicted offender expects the cost of a prison sentence $F\left(t_{i}\right)$ with conditional probability $p_{s \mid c}$ and non-custodial sentences with probability $\left(1-p_{s \mid c}\right)$. In the case of non-custodial sentences, offenders can still work in the legal sector, but their income after conviction, $L^{b}\left(t_{\ell}\right)$, will fall below $L\left(t_{\ell}\right)$ as a consequence of the criminal record. This situation contrasts with the case of informal sanctions or diversion: Despite previous detection, crime suspects are protected from any stigmatizing effect such that their potential legal and illegal earnings coincide with those of undetected criminals or full-time employees who work legally and who all earn $L\left(t_{\ell}\right)$ and $G\left(t_{i}\right)$. This situation arises with probability $(1-p)$.

Summing up, three different situations need to be considered. First, in case of non-detection, pre-trial diversion or court's dismissal, individual utility would be

$$
U\left[A+L\left(t_{\ell}\right)+G\left(t_{i}\right)\right],
$$

emerging with probability (1-p). If detected, brought to court and convicted, either utility

$$
U\left[A+L^{b}\left(t_{\ell}\right)+G\left(t_{i}\right)\right]
$$

occurs in case of non-custodial sentences with probability $p\left(1-p_{s \mid c}\right)$, or

$$
U\left[A+G\left(t_{i}\right)-F\left(t_{i}\right)\right]
$$

would apply with probability $p p_{s \mid c}$, where $U$ is individual's utility function, and

$$
\begin{array}{lll}
L\left(t_{\ell}\right)= & \text { legal income, } \\
L^{b}\left(t_{\ell}\right)= & \text { legal income after previous conviction (adjusted for non-custodial } \\
& \text { sentences such as fines), with } L\left(t_{\ell}\right)>L^{b}\left(t_{\ell}\right)>0, \\
G\left(t_{i}\right)= & \text { illegal gain, } \\
F\left(t_{i}\right)= & \text { cost function (monetary equivalent) of prison sentence, } \\
\mathrm{A} & =\quad \text { initial wealth. }
\end{array}
$$

The innovative element as compared to standard models of economics of crime is the distinction between $L$ and $L^{b}$. As $L^{b}$ covers legal income opportunities despite a preceding conviction, it is relevant for offenders who are convicted on probation or sentenced to fines. As the share of unconditional imprisonment is strongly declining over time at least in 
Germany $^{7}$, it would be misleading to retain the standard model of crime which does assume zero income for convicted offenders (as in equation 2.3). According to modern criminal law, imprisonment is considered as ultima ratio of the penal law. ${ }^{8}$ The idea behind this norm is that non-custodial sentences should prevent negative experiences behind bars (see Bayer et al., 2009, as well as Chen and Shapiro, 2007, for recent evidence on this issue) and enable convicted offenders to work in the legal sector, although previous records and fines cause an income gap such that expected payoffs are below those without conviction (see equation (2.2)). The difference $L\left(t_{\ell}\right)-L^{b}\left(t_{\ell}\right)$ can be interpreted as the stigma effect from previous convictions (Rasmussen, 1996, Funk, 2004), and the result of fines.

Individuals maximize expected utility, i.e

$$
\begin{gathered}
E(U)=p\left\{\left(1-p_{s \mid c}\right) U\left[A+L^{b}\left(t_{\ell}\right)+G\left(t_{i}\right)\right]+p_{s \mid c} U\left[A+G\left(t_{i}\right)-F\left(t_{i}\right)\right]\right\} \\
+(1-p) U\left[A+L\left(t_{\ell}\right)+G\left(t_{i}\right)\right],
\end{gathered}
$$

subject to the given time constraint. Unambiguous first-order conditions (see Appendix) require some further assumptions:

$$
\begin{array}{cl}
\text { I. } U^{\prime \prime}<0 & \text { risk aversion, } \\
\text { II. } G^{\prime \prime}\left(t_{i}\right)<0 & \text { decreasing marginal return to illegal activity, } \\
\text { III. } F^{\prime \prime}\left(t_{i}\right)>0 & \text { neoclassic functional form of sentencing costs, } \\
\text { IV. } F^{\prime}\left(t_{i}\right)>G^{\prime}\left(t_{i}\right) & \text { 'evil of punishment' }>\text { 'gain from offence'.9 }
\end{array}
$$

Under these conditions, first-order conditions of an interior maximum provide the following results:

\footnotetext{
${ }^{7}$ In Germany, in 2008 less than every tenth (8.0\%) judgment imposed an unconditional prison sentence. In 1950, this share was still at $39.1 \%$ (see Heinz, 2010).

${ }^{8}$ In the aftermath of the Criminal Law Reform (1969) the prevailing opinion is to avoid any criminal record, or, if conviction still seemed justified, to avoid imprisonment. The rationale behind this legal norm is that offenders, in particular young offenders, should not lose their future legal income opportunities, because this would increase the risk of recidivism. According to German criminologists, the 1969 reform was considered the most important change in criminal policy after World War II. The reform, also dubbed the 'Grand Criminal Law Reform” (Grosse Strafrechtsreform), came into force in 1975, and is thus fully covered by the panel data set (1977 - 2001) used in this paper. See Busch (2005) and Heinz (2006) for historical details of the reform.

9 This condition can be justified by Bentham's (1781) 'Principles of Morals and Legislation'. According to Rule 1 of his 'Of the Proportion between Punishments and Offences' The value of the punishment must not be less in any case than what is sufficient to outweigh that of the profit of the offence (p.141). Moreover, Rule 7 states To enable the value of the punishment to outweigh that of the profit of the offence, it must be increased, in point of magnitude, in proportion as it falls short in point of certainty (p.143/144).
} 


$$
\frac{\partial t_{i}}{\partial p}<0, \quad \frac{\partial t_{i}}{\partial p_{s \mid c}}<0, \frac{\partial t_{i}}{\partial\left(1-p_{s \mid c}\right)}>0, \frac{\partial t_{i}}{\partial F}<0, \frac{\partial t_{i}}{\partial\left(L\left(t_{\ell}\right)-L^{b}\left(t_{\ell}\right)\right)}<0 .
$$

Thus, in addition to classical results confirming the crime reducing effects of probability $(p)$ and severity $(F)$ of punishment, the results show that higher rates of non-custodial sentences increase crime. Thus, when courts change their judgment preferences towards probation and financial punishments, the model predicts increasing incentives to allocate time to illegal activities. Since $\mathrm{p}$ includes the probability of trial if detected, i.e. $p_{a c \mid c l}, \mathrm{p}$ is also driven by diversion. Hence the model also predicts that higher ratios of informal sentences, i.e. rising shares of suspects dismissed by public prosecutors, will increase crime rates.

Finally, the higher the stigma from a previous conviction, the higher is the effect of deterrence: ${ }^{10}$

$$
\frac{\partial t_{i} / \partial p}{\partial\left(L\left(t_{\ell}\right)-L^{b}\left(t_{\ell}\right)\right)}>0
$$

This effect is also called 'dynamic deterrence' in the literature because the threat of future income losses due to stigma would deter crime today (see Imai and Krishna, 2004).

Summing up, derived signs are consistent with expected effects of rational choice theory. However, as was already stated by Block and Heineke (1975), the signing of variables is not merely a theoretical question but demands econometric tests. They are going to be provided in Section 4 of this article.

\section{Criminal Prosecution: Institutional Background and Descriptive Evidence}

\subsection{Historical and Institutional Background}

European and U.S. criminal policies have followed quite different paths. Whereas Western European countries such as Germany adopted policies of diversion and non-custodial sentences, the U.S. faced the rising crime rates of the 1970s by greater incarceration and practicing 'tough on crime' strategies such as California's 'three strikes and you're out'. The

\footnotetext{
${ }^{10}$ Funk (2004), however, shows that while stigma deters unconvicted individuals from committing crimes, it may have undesirable side effects because it simultaneously enhances recidivism of a convicted and already stigmatized offender.
} 
incarceration rate in the U.S. state prison populations grew at an unprecedented rate, nearly quadrupling between the mid 1970s and the present, and reached the unprecedented number of 756 prisoners per 100,000 of the national population in 2006 (US Bureau of Justice Statistics). This rate is more than eight times higher than in Germany (89 per 100,000) and most other European countries (e.g. France 96, Sweden 74, Italy 92, Austria 95, England \& Wales 153; see Walmsley 2009).

The policy of increased incarceration leads to higher expenditures on the criminal justice system in the U.S. compared to Europe. However, the crucial question is whether the benefits from smaller imprisonment rates have been offset by higher costs of crime in response to decreasing general deterrence. A look at German data (see Figures 1 and 2) reveals that the number of convictions for theft rates started declining ever since the beginning of the 1990s, but convictions for assault show a strong upward trend. In total and for male adults, the number more than doubled since the beginning of the 1970s, for juveniles it quadrupled, and for females the number in 2009 is even more than sixfold the number of 1970.

Figure 1: Number of convictions for serious assault in West Germany, 1970-2009

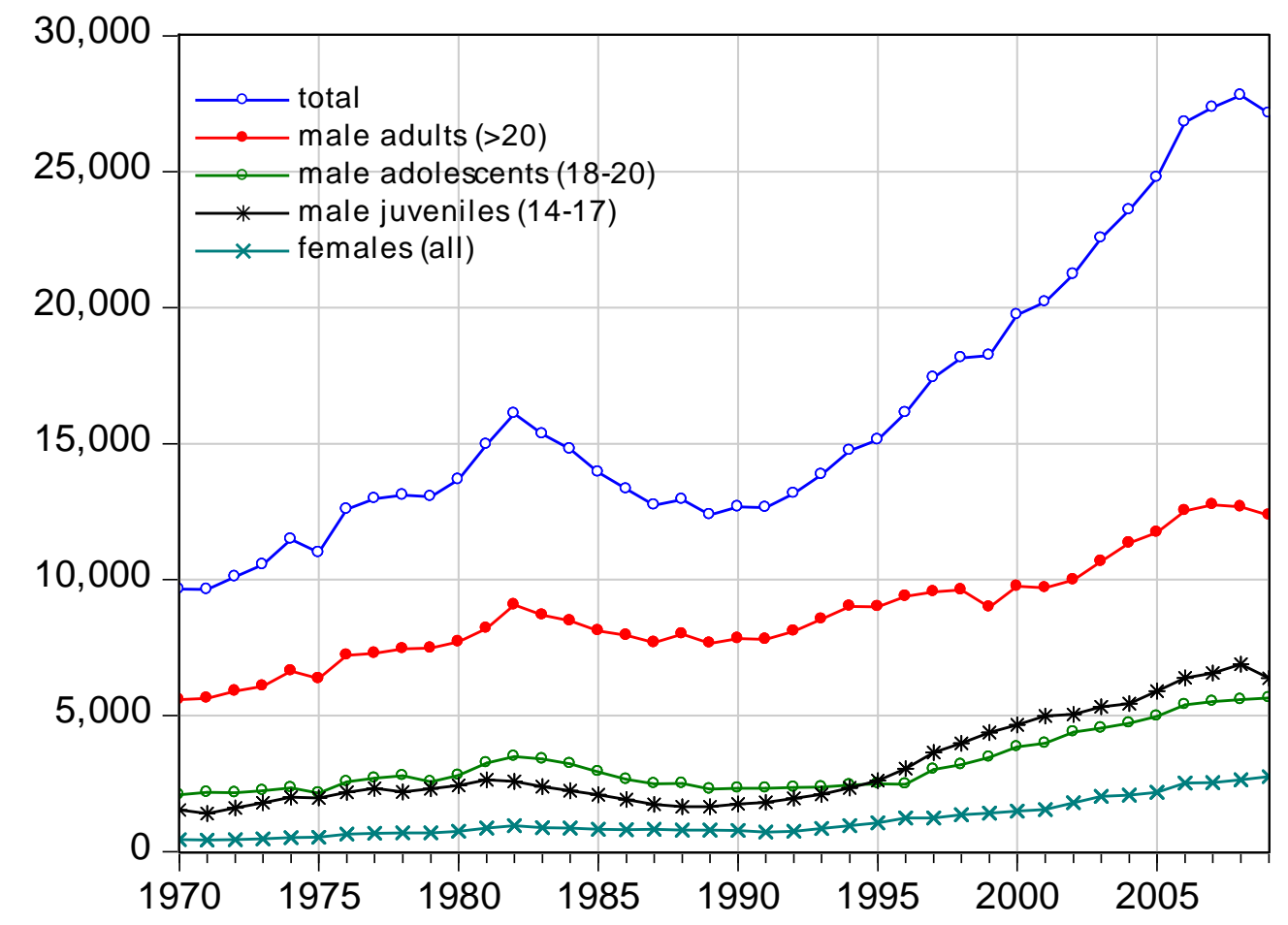

Notes: Total number of convictions for serious assault ('Gefährliche Körperverletzung’) in West Germany for different population groups; data include West-Berlin until 1994, after 1995 data cover united Berlin. Source: Statistisches Bundesamt (2010). 
A look across Europe shows that many countries have experienced similar developments (see Aebi, 2004, for evidence from 16 Western European countries, and Heiskanen, 2010, for international evidence). Heiskanen (2010), summarizing UN data, reports that in particular assault rates are rising, with the increase being larger from 2001 to 2006 as compared to the period 1996 to 2001. Also, the number of rapes and robberies augmented, but to a lesser extent. Property crimes (burglarly, theft rates) have declined.

Figure 2: Number of convictions for theft in West Germany, 1970-2009

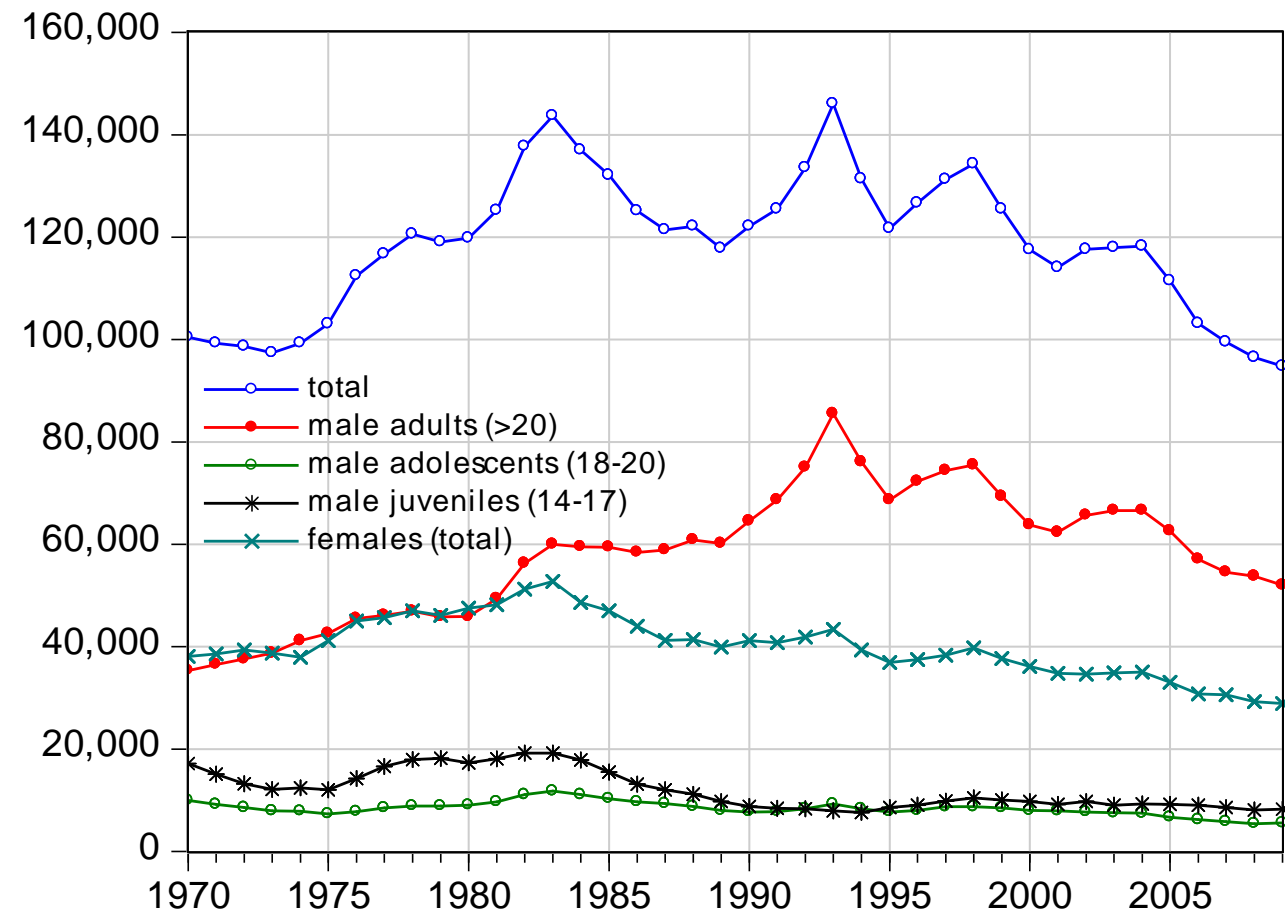

Notes: Total number of convictions for theft ('Diebstahl', § 242 StGB) in West Germany for different population groups; data include West-Berlin until 1994, after 1995 data cover united Berlin. Source: Statistisches Bundesamt (2010).

The German law enforcement experience is strongly influenced by the ideas of the Criminal Law Reform (1969). The prevailing opinion is to avoid any criminal record, or, if conviction still seemed justified, to avoid imprisonment. Criminal prosecution and sentencing practices are characterized by a strong downward trend of unconditional prison sentences (or, equivalently, increasing shares of non-custodial sentences) and a rising share of suspects whose cases are dropped because of "diversion"11. Following the idea of the proponents of the

\footnotetext{
${ }^{11}$ Formally, criminologists refer to 'diversion' as the circumvention of formal sanctioning (or sentencing) of a crime suspect who, based on the circumstances of the case, could be successfully prosecuted but whose case is dropped conditionally or unconditionally for so-called 'reasons of expediency'. Diversion can be applied in all
} 
Law Reform, affected suspects are considered as 'informally sanctioned' as their contact with the criminal system should be a shot across the bows and restrain them from future wrongdoing. Table 1 gives a first impression of the development of criminal prosecution over the last three decades in West Germany ${ }^{12}$ : The share of suspects who are convicted in a court decreased from $63.6 \%$ in 1981 to $41.8 \%$ in 2008 . Taking the remaining share of dismissals as $100 \%$, we observe that there is a steadily growing influence of prosecutors who were responsible for $86.8 \%$ of all dropped cases in 2008. The large majority of dismissals are without conditions. ${ }^{13}$

The growing influence of public prosecution has led to a strongly decreasing ratio of convictions to suspects which shrank from $63.5 \%$ in 1981 to $41.8 \%$ in 2008 (Table 1). Table 2 confirms that this falling ratio is not affected by a changing share of acquittals ordered by judges in a court. The share of convictions of suspects brought to court is pretty stable over time, with minima and maxima ranging between $81.3 \%$ in 1990 and $83.7 \%$ in 2000 .

Table 1: Convictions of criminal suspects in West Germany

\begin{tabular}{|c|c|c|c|c|}
\hline & \multirow{2}{*}{$\begin{array}{l}\text { Ratios of } \\
\text { convictions to } \\
\text { suspects }\end{array}$} & \multicolumn{2}{|c|}{ Share of dismissals $(=100)$} & \multirow{2}{*}{$\begin{array}{l}\text { Share of dismissals } \\
\text { (by prosecutor) } \\
\text { subject to conditions }\end{array}$} \\
\hline & & ordered by court & $\begin{array}{l}\text { ordered by } \\
\text { prosecutor }\end{array}$ & \\
\hline 1981 & 63.5 & 32.9 & 67.1 & 53.4 \\
\hline 1990 & 52.0 & 23.1 & 76.9 & 36.4 \\
\hline 2000 & 44.6 & 15.2 & 84.8 & 27.1 \\
\hline 2008 & 41.8 & 13.2 & 86.8 & 21.3 \\
\hline
\end{tabular}

Note: Percentage shares refer to all suspects under German adult and juvenile penal law. Data: Heinz (2010), p. 48-52; own calculations.

Table 2: Convictions of criminal suspects brought to court in West Germany

\begin{tabular}{|l|c|c|c|}
\hline & $\begin{array}{c}\text { Cases brought to court (in } \\
1000)\end{array}$ & $\begin{array}{c}\text { Share of } \\
\text { convictions }\end{array}$ & $\begin{array}{c}\text { Share of dismissals subject } \\
\text { to conditions }\end{array}$ \\
\hline 1980 & 735.2 & 81.6 & 24.2 \\
1990 & 756.3 & 81.3 & 18.3 \\
2000 & 763.3 & 83.7 & 17.3 \\
2008 & 761.5 & 83.3 & 17.9 \\
\hline
\end{tabular}

Note: Percentage shares refer to cases brought to court under German adult penal law. Data: Heinz (2010), p. 4852; own calculations.

cases concerning offences which are not punishable by a minimum penalty of one year or more (see Heinz, 2006, or Weigend, 1995, for details).

${ }^{12}$ Note that numbers in East Germany do not differ much from the development in West Germany (see Heinz, 2010).

${ }^{13}$ In 2008, the ratio of dismissals without further legal restraints to all dismissals (by courts and prosecutors) amounted to 87\% (own calculation based on Heinz, 2010, p. 49-52). 
The econometric evidence of this paper is based on 'adults' aged 21 years or more. The reason for this restriction is the German penal law which distinguishes between juveniles (persons aged 14 to 17 years), adolescents (18 to 20 years) and adults (21 years or more). The juvenile penal code makes frequent use of two forms of punishment not provided for in the general penal code, corrective penalties (educational aid and supervision, issuing of instructions) and disciplinary measures (mandatory labor service, juvenile detention). Furthermore, sentences pronounced according to the juvenile penal code are principally less severe, this being reflected in the fact that, for example, the longest sentence is only half as long as that provided for by the general penal code and that no juvenile sentence (not even for murder) exceeds 10 years. Adolescents (persons aged 18 to 20 years) are also excluded from the empirical analysis as it is at the discretion of the judge whether they are sentenced according to either the juvenile penal code or the general penal code, a circumstance which prevents econometric testing of any penal system for this age group (see Entorf, 2011, for the microeconometric analysis of the endogenous selection of adolescents to judicial systems).

\subsection{Descriptive Evidence on Criminal Prosecution in Germany}

In order to map the criminal prosecution process as comprehensively as possible, subsequent econometric evidence is based on two sources of official statistics - police crime statistics (PCS) and criminal prosecution statistics (StVStat). These data sets have been carefully matched by Spengler (2004, 2006) ${ }^{14}$ Information is acquired for seven 'classic' categories of crime (murder and manslaughter, rape and indecent assault, robbery, aggravated assault, serious theft, petty theft and fraud) for each of the former West German states for the period from 1977 - 2001. As the sample is restricted to the former West German part, it is possible to cover rather long time series. ${ }^{15}$

\footnotetext{
14 The creation of a comprehensive system of indicators for crime and prosecution requires merging data on crime and suspects from police data (PCS) with data on criminal prosecution collected by the German Statistical Office (StVStat). Among others, considerable difficulties were found in different registration categories in PCS and StVStat statistics, in treating offenders who have committed various offences which are simultaneously tried in court, the disparity between PCS and StVStat in the registration date, and revision of suspect counts in the PCS. As discussed at length in Spengler (2004, 2006), most of these data problems were dispelled by suitable approximations.

${ }^{15}$ However, given that the newly formed German states have had an impact on the overall German law system as well as on income, unemployment, population structure etc. after German unification in 1990, considering isolated 'West' or 'East' German universes more and more ceases to be a sensible research strategy. Considering a period such as 1977 to 2001 might thus be considered a compromise between the advantages of long time series on the one hand and structural changes in the population of interest on the other hand.
} 
Table 3 gives a more detailed impression of the development of the criminal prosecution and sentencing practice in Germany by looking at two major crime categories, i.e. serious theft and aggravated assault. ${ }^{16}$ Beginning with the clearance rate, Table 3, column (1), reveals high and quite stable clearance rates for assault (about 85\%), and much smaller rates for serious theft which declined from $19.3 \%$ in $1977-81$ down to $13.3 \%$ in $1998-2001$.

Table 3: The development of the sanctioning practice in Western Germany (Shares in \%)

\begin{tabular}{|c|c|c|c|c|c|c|}
\hline & $\begin{array}{c}(1) \\
\text { Crimes } \\
\text { cleared by } \\
\text { the police } \\
\text { (clearance } \\
\text { rate) }\end{array}$ & $\begin{array}{c}\text { Suspects } \\
\text { brought to } \\
\text { court } \\
\text { (indictment } \\
\text { rate) }\end{array}$ & $\begin{array}{c}\text { Defendants } \\
\text { convicted in } \\
\text { a trial (court } \\
\text { conviction } \\
\text { rate) }\end{array}$ & $\begin{array}{c}\text { Convicts with } \\
\text { unconditional } \\
\text { imprisonment } \\
\text { (imprisonment } \\
\text { rate) }\end{array}$ & $\begin{array}{c}\text { Sentenced to } \\
\text { prison on } \\
\text { probation } \\
\text { (probation } \\
\text { rate) }\end{array}$ & $\begin{array}{c}\text { Sentenced } \\
\text { to fine (fine } \\
\text { rate) }\end{array}$ \\
\hline $1977-1981$ & 19.3 & 46.5 & 85.2 & 41.1 & 38.2 & 20.7 \\
\hline $1982-1986$ & 17.7 & 44.0 & 83.3 & 35.1 & 42.0 & 22.9 \\
\hline $1987-1992$ & 15.0 & 37.4 & 80.3 & 32.7 & 43.4 & 23.9 \\
\hline $1993-1997$ & 12.9 & 36.1 & 81.0 & 31.6 & 42.9 & 25.5 \\
\hline $1998-2001$ & 13.3 & 35.4 & 81.3 & 36.3 & 42.5 & 21.1 \\
\hline Aggravated & & & & & & 6.5 \\
\hline Assault & 86.2 & 35.1 & 64.0 & 10.1 & 20.9 & 69.0 \\
\hline $1977-1981$ & 85.6 & 34.7 & 63.4 & 11.2 & 23.9 & 64.8 \\
\hline $1982-1986$ & 84.0 & 31.2 & 61.1 & 10.6 & 24.3 & 65.1 \\
\hline $1987-1992$ & 83.5 & 30.3 & 63.4 & 10.4 & 29.2 & 60.4 \\
\hline $1993-1997$ & 30.4 & 63.6 & 14.7 & 49.7 & 35.5 \\
\hline $1998-2001$ & 85.0 & 30.4 & & & \\
\hline
\end{tabular}

Notes: Average rates (in percent) of listed time periods; rates of clearance, indictment and conviction refer to the total of all age groups (at least 14 years of age), rates of imprisonment, probation and fine refer to the adult penal law (21 years or older). Data sources: PCS, StVStat, Spengler (2004), own calculations.

After suspects are detected by the police, it then becomes the task of the public prosecutor's office to legally and factually evaluate the accusation and to reach a final decision regarding the investigative procedure. Essentially, the latter can result in the case being dropped owing to the uncertain probability of sentencing, in diversion or in an indictment. In the case of an

\footnotetext{
${ }^{16}$ Descriptive statistics of included variables are presented in the Appendix.
} 
indictment the suspect is subject to sentencing by a court. In Table 3, column (2), the share of cases passed on to court is referred to as the indictment rate. The large drop in criminal proceedings confirms the highly influential discretionary power of the public prosecutor at the crime-category level. During the last period of investigation, 1998 - 2001, only 35.4\% of suspects of serious theft and $30.4 \%$ of assaults were brought to court. Both rates fell throughout the period of investigation, in particular during the 1980s. They came down from $46.5 \%$ to $35.4 \%$ for theft (average rates of the period 1977/1981 compared to the period 1998/2001) and from 35.1 to 30.4\% for assault. Put differently, in the most recent period of the sample, almost $70 \%$ of police clear-ups are discharged by public prosecutors through the channel of pre-trial diversion.

The trial can result in acquittal, in the proceedings being dismissed or end in a conviction. In contrast to the indictment rate, the proportion of trials resulting in a conviction, i.e. the court conviction rate ${ }^{17}$, remained rather stable, as can be seen from the examples of theft and assault in Table 3, column (3). The ratio of acquittals and dismissals based on trials in case of serious assault, however, significantly exceeds that of serious theft (37\% versus $17 \%$, on average). Regarding the certainty of a conviction, it is straightforward to calculate the product of indictment rates and court conviction rates, yielding the ratio of suspects brought to and convicted in a court. Henceforth this proportion is defined as the (overall) conviction rate.

In as far as a sentence is passed, the judge's verdict can, according to the adult penal code, take the form of either a non-suspended prison sentence, a suspended prison sentence - i.e. one which is suspended on probation - or a fine. The corresponding indicators are imprisonment rate, probation rate and fine rate, respectively (Table 3, columns (4) to (6)). For the various forms of punishment the severity of the penalty is measured by the length of the non-suspended prison sentence handed down and by the number of per-diem fines, respectively. Table 3 reveals unclear trends of the imprisonment rate. Proportions were low and stable at about $10 \%$ for aggravated assault and decreasing for serious theft from $41.1 \%$ down to $31.6 \%$ during the 1980 s and early 1990s, indicating that incarceration was driven back in favor of probation and financial fines, as suggested by the reform of 1969. However, from 1998 on imprisonment (from 10.4\% up to 14.7\%) and probation rates (from 29.2\% up to $49.7 \%$ ) for aggravated assault rose sharply, while the fine rate dropped from $60.4 \%$ down to $35.5 \%$.

\footnotetext{
${ }^{17}$ Note that we distinguish between the conviction rate performed in a court and the conviction rate defined as the ratio of convictions to suspects with the latter being consistent with the theoretical and econometric meaning of 'convictions'.
} 
The somewhat more punitive behavior from the late 1990s onwards is the result of a 1998 reform of the reform of 1969 (see Busch, 2005, for the history of all reforms since the Grand Criminal Law Reform of 1969). This reform (6th Strafrechtsreformgesetz) is the legislative outcome of preceding discussions on the inconsistency of existing sentences and degrees of penalties with the Werteordnung (value system) of the German Constitution. The debate was raised because sentences for violent crimes appeared to be unjustifiably lenient compared to sentences for property crimes. As a consequence, in a reform of the Grand Reform new (more severe) maximum and minimum penalties were introduced for many violent crimes (for example: the minimum/ maximum penalty for aggravated assault was 3 months/ 5 years before the reform, and it is 6 months/ 10 years after the reform).

Summing up, the most prominent trend of the German sentencing practice is the tendency towards lower indictment rates (see Table 3, column 2) which is in line with the idea of the German Criminal Law Reform (1969) and confirms the increasing importance of diversion and informal sentencing in Germany (see Heinz, 2006, 2010, for more descriptive evidence).

Regarding the long time span of included time series, it is necessary to consider changes in the demographic structure. In Germany, the ratio of the young population under 20 years of age to the population between 20 to under 65 years decreased from 0.53 in 1970 to 0.33 in 2005, whereas at the same time the ratio of the population older than 65 years to the active population aged 20 to 64 years increased from 0.25 to 0.32 (Source: Statistisches Bundesamt, 2006). Figure 3 depicts the demographic change (left panel) and the age structure of crime suspects (right panel) for selected German regions of the sample period of 1977 to 2001 . Taking aggravated assaults as a example, crime suspects of the age group 20 to 64 years follow the hump shaped time series of the demographic change, but the drop of their share in total crimes during the 1990s is stronger than the drop of the share of the same age group in the resident population, indicating strongly increasing shares of juveniles and adolescents in the group of offenders.

Thus, ignoring the changing share of crime-prone aged people would lead to a downward bias of crime rates of the active population. In order to adjust for demographic changes and to focus on persons in the 'criminally active' age group, age specific crime rates should be considered in the econometric analysis. As these are not available, they have been approximated under the assumption that the (unknown) age distribution of criminals is similar to the (known) age distribution of suspects. The approximation of the adjusted number of offenses is conducted according to the formula 


$$
O_{\text {cast }}=C A S E S_{\text {cst }} \times\left(S P_{\text {cast }} / S P_{\text {cst }}\right) \times\left(1 / P S_{\text {ast }}\right) \times 100.000,
$$

where CASES represents the number of cases recorded by the police, SP the number of crime suspects, and PS the size of population. The indices identify the offence group (c), the age group (a), the federal state (s) and the year (t). Subsequent econometric analyses consider the criminally active population of persons aged 21 to 59 years, who are exclusively subject to the general penal code. ${ }^{18}$

Figure 3: Demographic Changes of the German Resident Population and of Crime Suspects
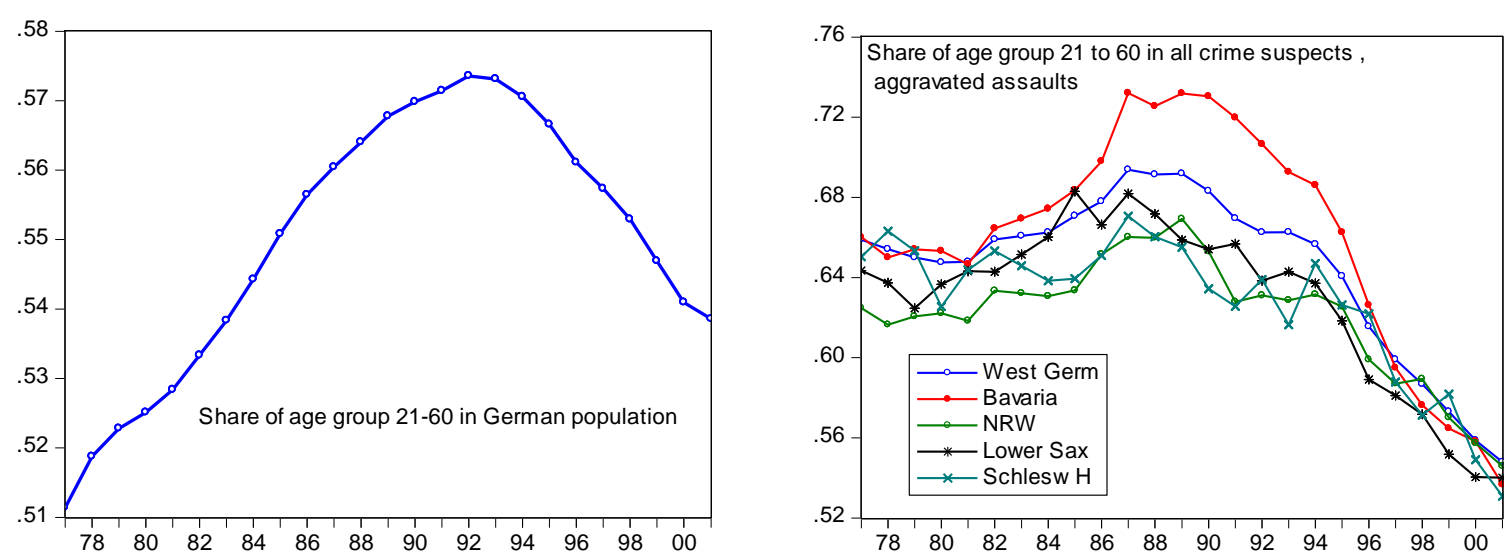

Data: Statistisches Bundesamt, Polizeiliche Kriminalstatistik (PCS), own calculations.

\subsection{Heterogeneity of Criminal Policy at the State Level}

Germany's 16 states (the German 'Laender') enjoy a certain autonomy, in particular in the areas of law, education, social assistance, and police, within a federal system. Thus, different views, traditions, religious roots and political majorities have led to divergent attitudes and political beliefs. This institutional setting makes the German Criminal Law Reform of 1969, which introduced the possibility of alternative sanctions into the judicial system and strengthened the discretionary power of public prosecutors, an interesting starting point for studying different crime policies. Despite a generally binding German penal code, some northern states such as Lower Saxony, Bremen and Schleswig Holstein showed high rates of compliance with the fundamental idea of more lenient sanctioning, whereas in particular the southern states of Bavaria and Baden-Wuerttemberg followed a more conservative 'tough on

\footnotetext{
${ }^{18}$ According to BKA (2010), only 6.9\% of suspects were 60 years or older in 2009 (in 2003, the share amounted to $6.3 \%$, see BKA, 2004).
} 
crime' criminal policy and were rather reluctant to adopt the liberal elements of the Criminal Law Reform.

The heterogeneity at the state level can be illustrated by the examples of Bavaria and Schleswig-Holstein. Bavaria is proving to be largely resistant to the long-term federal trend towards diversion. Despite the federally binding penal code, Bavaria also follows a harsher course concerning type and severity of sentence, with non-suspended prison sentences being markedly more frequent than in the federal average, and of a longer duration. SchleswigHolstein can be considered a representative of a more lenient criminal policy. The state's administration of justice repeatedly avowed its persuasion that alternative sentencing practices and diversion are effective measures that prevent crime through avoidance of formal convictions. ${ }^{19}$ The different notions of adequate strategies for fighting crime in both states can be seen by significantly higher imprisonment rates in Bavaria and in particular by the strongly divergent length of imprisonment throughout the 1990s, indicating strong compliance with the Criminal Law Reform of 1969 in Schleswig-Holstein and less or no compliance in Bavaria.

Table 4 gives details on the discrepancies between the two states. As regards the role of the public prosecutor, the most remarkable differences can be detected for assault and theft. Whereas conviction rates for assault were about the same in both states and even higher for theft in Schleswig-Holstein than in Bavaria before 1990, the recent period shows a strongly reverted picture: The probability of 'conviction' (i.e. indictment and subsequent conviction of a crime suspect in a court) dropped from $19.4 \%$ to $14.2 \%$ for aggravated assault (Bavaria: increase from $19.5 \%$ to $19.7 \%$ ), from $46.4 \%$ to $26.4 \%$ for petty theft (Bavaria: increase from $37 . \%$ to $38.1 \%$ ) and from $43.5 \%$ to $27 \%$ for serious theft (Bavaria: decrease from $35.9 \%$ to 31.6\%). During the period 1991-2001, all average conviction rates of the Bavarian justice exceeded those of Schleswig-Holstein. While these differences are mainly caused by the discretionary power of public prosecutors, also judges act according to respective statespecific judiciary norms. With the exception of murder, Bavarian courts impose unconditional prison sentences more often than courts in the northern state Schleswig-Holstein, where judges have the strong propensity to divert defendants from custody. Some of these contrasts are quite remarkable. In Bavaria, for instance, robbers receive a prison term in 64.2 cases out of 100 court convictions in Bavaria, but in Schleswig Holstein this rate is just 48.0 out of 100 .

\footnotetext{
${ }^{19}$ In 1990, the state passed a bill that renewed and extended the idea of the federal reform of 1969.
} 
Table 4: Discretionary sanctioning practices at the state level: Bavaria versus SchleswigHolstein

\begin{tabular}{|c|c|c|c|c|c|}
\hline & & \multicolumn{2}{|c|}{ Bavaria } & \multicolumn{2}{|c|}{ Schleswig-Holstein } \\
\hline \multirow{7}{*}{$\begin{array}{l}0 \\
0 \\
\Xi \\
\leq \\
\Xi \\
0 \\
\Xi \\
0 \\
0 \\
= \\
D \\
0 \\
0\end{array}$} & & 1977-1990 & $1991-2001$ & 1977-1990 & 1991-2001 \\
\hline & Murder/ Manslaughter & 28.0 & 28.0 & 23.0 & 27.4 \\
\hline & Rape and indecent ass. & 29.7 & 28.8 & 24.3 & 21.1 \\
\hline & Robbery & 29.3 & 29.1 & 30.8 & 25.6 \\
\hline & Aggravated assault & 19.5 & 19.7 & 19.4 & 14.2 \\
\hline & Petty theft & 37.0 & 38.1 & 46.4 & 26.4 \\
\hline & Serious theft & 35.9 & 31.6 & 43.5 & 27.0 \\
\hline \multirow{6}{*}{$\begin{array}{l}\text { ت } \\
\Xi \\
0 \\
ت \\
0 \\
0 \\
0 \\
\Xi \\
\Xi \\
0 \\
\Xi \\
0 \\
\overrightarrow{0} \\
\overrightarrow{0} \\
\overrightarrow{0}\end{array}$} & Murder/ Manslaughter & 93.8 & 93.4 & 93.1 & 95.1 \\
\hline & Rape and indecent ass. & 60.3 & 55.0 & 54.0 & 49.5 \\
\hline & Robbery & 72.6 & 63.5 & 64.2 & 48.0 \\
\hline & Aggravated assault & 12.0 & 14.0 & 10.4 & 10.6 \\
\hline & Petty theft & 8.6 & 7.2 & 3.8 & 2.8 \\
\hline & Serious theft & 44.2 & 35.2 & 32.7 & 25.2 \\
\hline \multirow{7}{*}{ 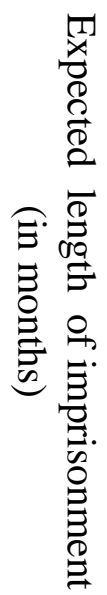 } & & & & & \\
\hline & Murder/ Manslaughter & 23.2 & 25.4 & 19.6 & 24.5 \\
\hline & Rape and indecent ass. & 5.1 & 5.7 & 3.0 & 3.1 \\
\hline & Robbery & 5.4 & 4.9 & 4.3 & 2.4 \\
\hline & Aggravated assault & 0.26 & 0.40 & 0.23 & 0.20 \\
\hline & Petty theft & 0.10 & 0.08 & 0.05 & 0.02 \\
\hline & Serious theft & 0.58 & 0.41 & 0.38 & 0.13 \\
\hline
\end{tabular}

Notes: Rates are adjusted for changes in the structure of the German residential population and restricted to the age group of 21 to under 60 years (see the text for details); entries represent averages of denoted time periods in percent. Conviction rate $=$ (indictment rate) $\mathrm{x}$ (rate of conviction in court decisions); expected length of imprisonment $=$ (clearance rate) $\mathrm{x}$ (conviction rate) $\mathrm{x}$ (imprisonment rate) $x$ (average length of imprisonment). 
Given precedent probabilities of conviction and imprisonment, it is not surprising that also expected values of the expected length of imprisonment differ substantially. In Table 4, the expected duration is defined as the product of the clearance rate, conviction rate, imprisonment rate and the average (realized) length of the prison sentence. In Bavaria, offenders of all types of crime face longer expected prison terms than in Schleswig-Holstein. After 1990, albeit at a low level, most expected durations in Bavarian prisons are more than twice the Schleswig-Holstein value. Given that all crimes were reported to the police, in Schleswig-Holstein robbers would take the risk of 2.4 months in custody (compared to 4.9 months in Bavaria), committing rape and sexual assault would imply the risk of 3.1 months (5.7 months in Bavaria), aggravated assault would cause just 6 days in prison (12 days in Bavaria), and the expected prison sentences for serious theft and petty theft were 4 days and 0.6 days (12 days and 2.4 days), respectively.

\section{Econometric Evidence}

\subsection{Econometric Modeling and Methodological Aspects}

The econometric model is based on the theoretical framework of informal, custodial and noncustodial sentencing derived in Section 2, eventually leading to the augmented version of the classical supply of offences:

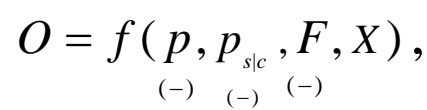

where the parameter $p$ represents the certainty of conviction; it can be factorized into $p_{c l}$ (clearance rate) and $p_{c v \mid c l} \equiv p_{a c \mid c l} p_{c v \mid a c}$ (conviction, given arrest). ${ }^{20}$ The parameter $p_{s \mid c}$ represents the imprisonment rate, i.e. the probability of an unconditional prison sentence, given conviction. The second element of 'severity' of imposed sanctions is the strength of the sanction, F.

Previous descriptive evidence has revealed that criminal prosecution indicators display a high variation both across the federal states and throughout the observation period. The econometric analysis will thus make use of the conviction rate rather than considering

\footnotetext{
${ }^{20}$ The impact of $L\left(t_{\ell}\right)-L^{b}\left(t_{\ell}\right)$ has not been tested; there are no regional data on the difference between wages with and without criminal record. Therefore, testing the criminal stigma impact must be left for future research.
} 
separate indictment and court conviction rates, having in mind that the variance of the (overall) conviction rate is mainly driven by public prosecution activities over time and across states. The following variables related to police, public prosecution and courts will be included:

- Clearance rate $=$ total cleared cases / total registered cases,

- Conviction rate $=\quad$ persons indicted and convicted in a court/ suspects, aged 21 to under 60 years,

- $\quad$ Imprisonment rate $=$ non-suspended imprisonment / convicted, aged 21 to under 60 years,

- $\quad$ Probation rate $=$ sentenced to suspended imprisonment/ convicted, aged 21 to under 60 years,

- $\quad$ Fine rate $=$ sentenced to fine (as most severe sentence)/convicted, aged 21 to under 60 years,

- Average length (in months) of non-suspended prison sentence of persons sentenced aged from 21 to under 60 years.

The crime rate will be subsequently related to the criminal prosecution indicators described above and to further explanatory variables derived from the economic theory of crime. The latter consist of the real per-capita gross domestic product and the unemployment rate, both representing legal and illegal income opportunities. Moreover, the share of young males between 15 and 24 as well as the share of migrants in the population cover demographic heterogeneities of crime-prone risk groups. ${ }^{21}$ The time series of Berlin are disregarded because of their structural break after the fall of the Berlin Wall in 1989. Descriptive statistics are summarized in Table A1 (Appendix).

The general estimation strategy is grounded on the fact that the observed crime rate, which relies on the number of crimes reported to the police, does not coincide with the actual crime rate. However, assuming that "observed number of crimes $=$ share of crimes reported to the police $\times$ actual number of crimes $\times$ measurement error”, i.e.

$$
O_{i t}=\omega_{i}^{*} \theta_{t}^{*} O_{i t}^{*} u_{i t} \Rightarrow \ln O_{i t}=\ln O_{i t}^{*}+\omega_{i}+\theta_{t}+\varepsilon_{i t},
$$

where

$$
\begin{aligned}
& O_{i t}=\text { number of crimes reported to the police in state } \mathrm{i} \text { and year } \mathrm{t}, \\
& \omega_{i}^{*}=\text { share of crimes reported to the police in state } \mathrm{i},
\end{aligned}
$$

\footnotetext{
${ }^{21}$ The German Police statistics (PCS) do not distinguish between migrants with and without German citizenship. For this reason, 'migrants' cover the share of foreign nationals in the German resident population.
} 


$$
\begin{aligned}
& \theta_{t}^{*}=\text { share of crimes reported to the police in year } \mathrm{t}, \\
& u_{i t}=\text { residual error term of state } \mathrm{i} \text { and year } \mathrm{t},
\end{aligned}
$$

taking logs of (4.2) yields an estimable econometric model of crime depending on explanatory factors as well as on state and year effects covering unobserved heterogeneity in the error term:

$$
\ln \left(O_{i t}\right)=a_{0}+a_{1} x_{1 i t}+\ldots+a_{K} x_{K i t}+e_{i t} \text {, where } e_{i t}=\omega_{i}+\theta_{t}+\varepsilon_{i t} \text {. }
$$

Results by Cornwell and Trumbull (1994) reveal that disregarding unobserved heterogeneity would lead to substantial overestimation of deterrence effects. Sources of such biases can also be seen, for example, in the basic attitude of the state population towards illegal acts, in the peculiarities of the state prosecution systems which are not accounted for by the prosecution indicators deployed, especially in varying levels of underreporting, or in changes of the measurement of the endogenous variable such as changing definitions of and allocations to crime categories.

The particular econometric model to be estimated is as follows:

$$
C_{k i t}=\alpha+D_{k i t} \beta+X_{i t} \delta+\lambda_{k}+\omega_{k i}+\theta_{k t}+\varepsilon_{k i t},
$$

where $C_{k i t}$ is the crime rate (in logs) per 100,000 inhabitants for category $k$ in state $i$ and time $t$. $\mathrm{D}$ is the set of deterrence and criminal prosecution variables considered in the theoretical model and equation (4.1); $X$ is the vector of covariates discussed above. Equation (4.4) represents the econometric model for two pooled and generalized crime categories (see Levitt, 1997, 2002, for a similar approach). First, cross-crime parameter restrictions are constrained to be identical for all violent crimes, i.e. $k=$ murder and assault, rape and indecent assault, aggravated assault. In the second estimation model, all property crimes, i.e. $k=$ theft, robbery, and fraud, are summarized. The advantage of this estimation strategy is that it provides a more concise summary of the effects and, given the imposed restrictions are valid, more precise point estimates. The potential drawback of the restrictions is that imposed restrictions may give a misleading picture of structural parameters. Therefore, estimates of individual crime categories of the impact of police, prosecutors and court decisions will be presented in the Appendix (Tables A4 and A5).

The basic estimation method is pooled FGLS, where category-specific weights allow for heteroskedasticity across crime categories. The estimation includes state-specific effects to capture crime-specific variation across German states, and year dummies which ought to 
cover crime-specific trends. The estimation is based on a category-specific SUR covariance structure which allows for conditional correlation between the contemporaneous residuals for crime categories $k$ and $l$, but restricts residuals in different categories to be uncorrelated. Specifically, we assume that

$$
E\left(\varepsilon_{k i t} \varepsilon_{l i t} \mid x_{k}^{*}\right)=\sigma_{k l}, \quad E\left(\varepsilon_{k i t} \varepsilon_{l s j} \mid x_{k}^{*}\right)=0 \quad \text { for all it } \neq s j \text {, }
$$

i.e.

$$
\Omega_{K}=\left(\begin{array}{ccc}
\sigma_{11} & \ldots & \sigma_{1 K} \\
& \ddots & \\
\sigma_{K 1} & \ldots & \sigma_{K K}
\end{array}\right)
$$

involves covariances across cross-sections (i.e. crime-categories) as in a seemingly unrelated regressions type framework. Robust standard errors are calculated using the panel corrected standard error (PCSE) methodology (Beck and Katz, 1995; Reed and Ye, 2009).

There is no scholary consensus as to the critical question whether crime rates must be differenced or not. In Entorf and Spengler (2008) ADF unit root tests reveal that a large fraction of log-crime rates (in particular for property crimes) have a unit root or are close to a unit root. However, for other time series as the one for murder and manslaughter as well as for rape and indecent assault the null on nonstationarity is clearly rejected. At the same time, explanatory variables such as GDP, unemployment or share of migrants all are nonstationary. Spelman (2008) comes to the conclusion that in situations like this the best specification of the crime equation must rely on differenced data, and that alternative specifications run a substantial risk of spurious results (see also Entorf, 1997). The econometric approach in this paper follows Spelman's suggestion; all estimates use growth rates of dependent and explanatory variables.

\subsection{Estimation Results}

Table 5 and Table 6 show econometric results for property crimes and violent crimes, respectively. The model specification includes the imprisonment rate, $p_{s \mid c}$, i.e. the remaining 
sum of more lenient sanctions (probation rate + fine rate) is used as reference category. ${ }^{22}$ Table 5 comprises elasticity estimates of structural parameters $p_{c l}, p_{c v \mid c l}$ and $p_{s \mid c}$ for property crimes (serious theft, robbery, theft without aggravating circumstances, and fraud). Column (1) shows estimations including both time and state effects. ${ }^{23}$ As expected with differenced data, state effects turn out to be insignificant. Table 5, column (2), presents estimates without state effects; here F-tests indicate non-negligible period effects. Robustness of results is checked and confirmed in column (3), where state effects are re-included without time effects, and in column (4), where neither time nor state effects are estimated. Finally, Table 5, column (5) highlights the potential omitted variable bias which might arise when the influence of public prosecution and courts is ignored in the econometric model.

As regards the certainty of the punishment, econometric results in Table 5 confirm theoretical predictions. Clearance rate and conviction rate both have negative signs and estimated parameters are highly significant. When inspecting Table 5, column (2), representing the most reliable specification, the conviction elasticity of -0.228 is more pronounced than the response to changes in the probability of detection (clearance rate), which is -0.155 . Likewise in accordance with theory is the deterrent effect of potential unconditional imprisonment: The parameter estimate of $p_{s \mid c}$ is -0.055 (Table 5 , column (2)). Thus, regional or general trends towards probation and non-custodial sentences are associated with higher property crime rates. The second indicator of the severity of sanctions, length of imprisonment terms, is insignificant throughout all specifications. A comparison of presented estimates to previous results using German data is not straightforward, as former tests of the deterrence hypothesis are based on an incomplete set of criminal prosecution variables. As regards the significance of clearance rates, results align with findings in Entorf and Spengler (2000) and Entorf and Winker (2008).

Testing significance of parameters using differenced data in addition to the inclusion of time and state effects can be considered a rather conservative estimation strategy. Perhaps not surprisingly, significance of covariates is reduced when time effects are included, as can be seen from comparing column (2) (Table 5) to columns (3) and (4). Parameters on covariates

\footnotetext{
${ }^{22}$ Of, course, fines are not always applicable (e.g. in case of murder/ manslaughter) such that the ratio of fines is zero in these cases.

${ }^{23}$ In general, data cover the time series 1977 to 2001, leading to 240 observations (in growth rates). Different starting points for few states, and, following some communication with representatives of the German Statistical Office, omitting faulty and evidently misrecorded data points causes eight missing values such that Tables 5 and further results are based on 232 observations.
} 
based on estimations without period effects are in line with expectations and confirm previous results found in the literature: Higher unemployment (see, e.g., Raphael and Winter-Ebmer ,2001; Lin, 2008), higher shares of migrants as well as higher ratios of young males increase the risk of property crime rates. GDP per capita, however, is not found to be related to property crime rates.

Table 5: Property crimes (serious theft, robbery, petty theft, fraud)

\begin{tabular}{|c|c|c|c|c|c|}
\hline Explanatory Variables & (1) & $(2)$ & (3) & (4) & (5) \\
\hline Clearance rate, $p_{c l}$ & $\begin{array}{c}-0.148 * * \\
(0.037)\end{array}$ & $\begin{array}{c}-0.155^{* *} \\
(0.036)\end{array}$ & $\begin{array}{c}-0.278 * * \\
(0.045)\end{array}$ & $\begin{array}{c}-0.283^{* *} \\
(0.044)\end{array}$ & $\begin{array}{l}-0.046 \\
(0.040)\end{array}$ \\
\hline Conviction rate, $p_{c v \mid c l}$ & $\begin{array}{c}-0.229 * * \\
(0.019)\end{array}$ & $\begin{array}{c}-0.228 * * \\
(0.019)\end{array}$ & $\begin{array}{c}-0.288 * * \\
(0.023)\end{array}$ & $\begin{array}{c}-0.288 * * \\
(0.023)\end{array}$ & - \\
\hline Imprisonment rate, $p_{s \mid c}$ & $\begin{array}{c}-0.055^{* *} \\
(0.016)\end{array}$ & $\begin{array}{c}-0.055^{* *} \\
(0.016)\end{array}$ & $\begin{array}{c}-0.098 * * \\
(0.020)\end{array}$ & $\begin{array}{c}-0.098^{* *} \\
(0.020)\end{array}$ & - \\
\hline $\ln$ (length of imprisonment), $F$ & $\begin{array}{c}0.033 \\
(0.021)\end{array}$ & $\begin{array}{c}0.029 \\
(0.020)\end{array}$ & $\begin{array}{c}0.032 \\
(0.025)\end{array}$ & $\begin{array}{c}0.031 \\
(0.025)\end{array}$ & $\begin{array}{l}-0.003 \\
(0.022)\end{array}$ \\
\hline Per-Capita GDP & $\begin{array}{c}-0.066 \\
(0.171)\end{array}$ & $\begin{array}{c}-0.092 \\
(0.165)\end{array}$ & $\begin{array}{c}-0.045 \\
(0.187)\end{array}$ & $\begin{array}{l}-0.042 \\
(0.182)\end{array}$ & $\begin{array}{l}-0.181 \\
(0.189)\end{array}$ \\
\hline Unemployment rate & $\begin{array}{c}0.071 \\
(0.059)\end{array}$ & $\begin{array}{c}0.078 \\
(0.057)\end{array}$ & $\begin{array}{c}0.153 * * \\
(0.029)\end{array}$ & $\begin{array}{c}0.154^{* *} \\
(0.028)\end{array}$ & $\begin{array}{c}0.060 \\
(0.065)\end{array}$ \\
\hline Rate of migrants & $\begin{array}{c}-0.098 \\
(0.121)\end{array}$ & $\begin{array}{c}-0.053 \\
(0.113)\end{array}$ & $\begin{array}{c}0.302 * * \\
(0.087)\end{array}$ & $\begin{array}{c}0.307 * * \\
(0.084)\end{array}$ & $\begin{array}{l}-0.017 \\
(0.130)\end{array}$ \\
\hline Share of young males & $\begin{array}{l}-0.073 \\
(0.282)\end{array}$ & $\begin{array}{c}0.016 \\
(0.261)\end{array}$ & $\begin{array}{l}0.247^{*} \\
(0.114)\end{array}$ & $\begin{array}{l}0.250^{*} \\
(0.111)\end{array}$ & $\begin{array}{c}0.078 \\
(0.298)\end{array}$ \\
\hline Crime-specific state effects? & yes $^{\text {a) }}$ & no ${ }^{c)}$ & yes ${ }^{c)}$ & no & no $^{\mathrm{c})}$ \\
\hline Crime-specific period effects? & yes** b) & yes** c) & no ${ }^{c)}$ & no & yes**c) \\
\hline Overall $\mathrm{R}^{2}$ & 0.623 & 0.615 & 0.263 & 0.257 & 0.532 \\
\hline Panel-DW & 2.54 & 2.49 & 2.10 & 2.09 & 2.50 \\
\hline Number of observations & 232 & 232 & 232 & 232 & 232 \\
\hline Total pool observations & 928 & 928 & 928 & 928 & 928 \\
\hline
\end{tabular}

Notes: Robust cross-section SUR (PCSE) standard errors (d.f. corrected) in parentheses; ${ }^{* *}$ ), ${ }^{*}$ ) significant at the 1 and 5 percent level; a) Tested (F-tests) against 'state effects=no, period effects = yes'; b) tested against 'state effects=yes, period effects = no'; c) tested against 'state effects=no, period effects $=$ no'.

As suggested by Mustard (2003) and Mendes and MacDonald (2001), among others, ignoring some integral part of the criminal prosecution and criminal deterrence mechanism might 
cause a serious omitted variable bias. This can be seen from Table 5, column (5), where the impacts of public prosecutors as well as of judges are not taken into account. Here, even after including period effects which might compensate for omitted time-dependent variation, the clearance rate turns out to be insignificant, while it was clearly significant throughout all fully specified models.

Replicating the same estimation procedure for violent crimes (murder/ manslaughter, rape and indecent assault, serious assault; see Table 6) leads to similar results, but with one important exception: In contrast to property crime, there is no significant effect coming from the severity of sanctions. Other results, such as the strong effect regarding certainty of conviction are confirmed, with responses to the clearance rate being even more pronounced than in Table 5. Again, there is indication that variations of high-risk population groups (young males, share of migrants) are positively related to crime rates. Comparing the size of parameter estimates in Table 5 to those of Table 6 reveals that violent crime seems to be particularly strongly affected by the share of young males in the population. Unemployment and GDP growth interchanged roles. In Table 6, GDP per capita has a negative sign and is at least weakly significant in columns (3) and (4), whereas unemployment rates turn out insignificant. Finally, as with property crimes, ignoring the influence of prosecutors and judges would result in an omitted variable bias (Table 6, column (5)).

A problem of estimation with panel data - especially in the case of large time-series dimensions - is the existence of serial correlation of residuals. Serial correlation is mainly a problem of regression in levels (and not in first differences or growth rates) and might 'only' cause misleading estimates of standard errors (a problem which is counteracted by calculating autocorrelation- and heteroskedasticity-robust standard errors), but can, however, also be an indication of a misspecification of the model and, correspondingly, of biased estimation of coefficients themselves. Inspecting results of serial correlation tests in Tables 5 and 6, there are indications of overdifferencing, as the Panel DW-statistic (Bhargava et al., 1982) exceeds 2.5 in most specifications. In order to account for potential problems of (negative) serial correlation, equation (4.4) is re-estimated assuming $\varepsilon_{\text {kit }}=\rho \varepsilon_{\text {ki.t-1 }}+\eta_{k i t}$. Using small letters for growth rates and ignoring insignificant state effects, the transformed equation becomes

$$
c_{k i t}=\rho c_{k i . t-1}+\alpha(1-\rho)+\left(d_{k i t}-\rho d_{k i . t-1}\right) \beta+\left(x_{i t}-\rho x_{i . t-1}\right) \delta+\lambda_{k}(1-\rho)+\tilde{\theta}_{k t}+\eta_{k i t}
$$

(Durbin, 1960). Equation (4.7) (using restrictions (4.5) and (4.6)) is estimated using nonlinear least squares. Tables A2 and A3 (see Appendix) reveal that results based on specification (4.7) do not differ substantially from corresponding estimates based on equation (4.4). The 
only remarkable change is the more pronounced and negative effect of GDP per capita on violent crimes in specifications (3) and (4) which is significant after correcting for overdifferencing in Table A3, while it is not so in Table 6.

Table 6: Violent crimes (murder/manslaughter, rape and indecent assault, aggravated assault)

\begin{tabular}{|c|c|c|c|c|c|}
\hline Explanatory Variables & (1) & $(2)$ & (3) & (4) & (5) \\
\hline Clearance rate, $p_{c l}$ & $\begin{array}{c}-0.226 * * \\
(0.083)\end{array}$ & $\begin{array}{c}-0.225^{* *} \\
(0.081)\end{array}$ & $\begin{array}{c}-0.242 * * \\
(0.080)\end{array}$ & $\begin{array}{c}-0.239 * * \\
(0.080)\end{array}$ & $\begin{array}{c}-0.133 \\
(0.092)\end{array}$ \\
\hline Conviction rate, $p_{c v \mid c l}$ & $\begin{array}{c}-0.251^{* *} \\
(0.018)\end{array}$ & $\begin{array}{c}-0.251^{* *} \\
(0.018)\end{array}$ & $\begin{array}{c}-0.270 * * \\
(0.018)\end{array}$ & $\begin{array}{c}-0.271^{* *} \\
(0.018)\end{array}$ & - \\
\hline Imprisonment rate, $p_{s \mid c}$ & $\begin{array}{l}-0.006 \\
(0.013)\end{array}$ & $\begin{array}{c}-0.006 \\
(0.013)\end{array}$ & $\begin{array}{c}-0.008 \\
(0.013)\end{array}$ & $\begin{array}{l}-0.007 \\
(0.013)\end{array}$ & - \\
\hline ln(length of imprisonment), $F$ & $\begin{array}{c}0.020 \\
(0.018)\end{array}$ & $\begin{array}{c}0.019 \\
(0.018)\end{array}$ & $\begin{array}{c}0.020 \\
(0.018)\end{array}$ & $\begin{array}{c}0.020 \\
(0.017)\end{array}$ & $\begin{array}{c}0.021 \\
(0.021)\end{array}$ \\
\hline Per-Capita GDP & $\begin{array}{c}-0.281 \\
(0.270)\end{array}$ & $\begin{array}{c}-0.316 \\
(0.260)\end{array}$ & $\begin{array}{l}-0.410 \\
(0.217)\end{array}$ & $\begin{array}{c}-0.418 * \\
(0.210)\end{array}$ & $\begin{array}{l}-0.186 \\
(0.302)\end{array}$ \\
\hline Unemployment rate & $\begin{array}{c}-0.044 \\
(0.093)\end{array}$ & $\begin{array}{c}-0.044 \\
(0.089)\end{array}$ & $\begin{array}{c}0.001 \\
(0.033)\end{array}$ & $\begin{array}{c}0.000 \\
(0.032)\end{array}$ & $\begin{array}{c}-0.094 \\
(0.105)\end{array}$ \\
\hline Rate of migrants & $\begin{array}{c}-0.028 \\
(0.192)\end{array}$ & $\begin{array}{c}0.003 \\
(0.179)\end{array}$ & $\begin{array}{l}0.223^{*} \\
(0.100)\end{array}$ & $\begin{array}{l}0.222 * \\
(0.097)\end{array}$ & $\begin{array}{c}-0.031 \\
(0.208)\end{array}$ \\
\hline Share of young males & $\begin{array}{c}0.048 \\
(0.445)\end{array}$ & $\begin{array}{c}0.080 \\
(0.408)\end{array}$ & $\begin{array}{c}0.462 * * \\
(0.132)\end{array}$ & $\begin{array}{c}0.462 * * \\
(0.128)\end{array}$ & $\begin{array}{c}0.110 \\
(0.478)\end{array}$ \\
\hline Crime-specific state effects? & yes $^{\text {a) }}$ & no ${ }^{\text {c) }}$ & yes $^{c)}$ & no & no $^{\text {c) }}$ \\
\hline Crime-specific period effects? & yes* b) & yes* c) & no ${ }^{c)}$ & no & yes**c) \\
\hline Overall $\mathrm{R}^{2}$ & 0.401 & 0.397 & 0.302 & 0.297 & 0.201 \\
\hline Panel-DW & 2.57 & 2.56 & 2.52 & 2.50 & 2.63 \\
\hline Number of observations & 232 & 232 & 232 & 232 & 232 \\
\hline Total pool observations & 696 & 696 & 696 & 696 & 696 \\
\hline
\end{tabular}

Notes: Robust cross-section SUR (PCSE) standard errors (d.f. corrected) in parentheses; ${ }^{* *}$ ), *) significant at the 1 and 5 percent level; a) Tested (F-tests) against 'state effects=no, period effects = yes'; b) tested against 'state effects=yes, period effects = no'; c) tested against 'state effects=no, period effects $=$ no'.

Potential simultaneity between the crime rate and explanatory factors of deterrence might require the use of instrument variable estimators (IV estimators). When the incidence of crime is not only influenced by the clearance rate but also vice versa, estimates which do not account for the endogeneity of explanatory variables might lead to inconsistency problems. There are several conceivable reasons for the interrelation of crime rate and clearance. The 
size of the clearance rate might depend, for example, on the overloading of police resulting from an unexpected rise in crime. Owing to the overloading of police capacity the clearance rate will sink, the absolute number of cases solved remaining constant. Since the crime rate is rising simultaneously, the negative partial correlation between clearance rate and crime incidence would be overestimated in least-squares applications. This could be counterbalanced by a potential underestimation for at least two reasons. First, criminal policy would respond to increasing crime rates by allocating public resources to the police, resulting in higher clearance rates. A second reason is related to the share of undocumented crimes in the actual number of crimes which likewise depends on police resources, in particular for offence types revealed by monitoring/controls and/or random spot checks. ${ }^{24}$ This apparently would lead to spurious positive correlation between crime rates and clearance rates. Against this background, IV estimations are conducted with the goal of neutralising possible simultaneity relationships between crime rate and clearance rate. ${ }^{25}$

The successful application of IV estimations crucially depends upon the existence of adequate instrument variables which are correlated with the endogenous explanatory variables while being simultaneously uncorrelated with the error term. IV results in Table 6 depend on three extraneous exogenous variables and lagged endogenous variables. The first extraneous variable is public debt per capita. Following arguments put forward by Levitt (1997, 2002), it is reasonable to assume that increasing public spending would lead to more police such that detection probabilities are going up. The second extraneous variable is attempt ratio (reported uncompleted offences/reported offences): Regions with a relatively large number of attempts will attract more attention by the police such that clearance rates are expected to be higher. The third variable is the share of crimes committed in small villages (less than 20,000 inhabitants). The variation in rural crime scenes is associated with varying degrees of anonymity. As rural neighborhood is assumed to be associated with less anonymity, an increasing share of crimes committed in smaller villages is expected to be associated with a higher probability of detection. Both ratios emerge ex post from the realization of illegal activities and have no direct impact on endogenous variables. Finally, as estimation are

\footnotetext{
${ }^{24}$ One third of petty thefts in Germany, for example, are cases of shoplifting (Bundeskriminalamt, 2004, 2010). As a rule, however, registered cases of shoplifting are characterized by an offender being caught red-handed, the case being cleared immediately. If, ceteris paribus, the number of registered cases of shoplifting were now to increase through an increase (decrease) in controls, the petty-theft rate would then rise (fall) with simultaneously increasing (decreasing) specific clearance rate.

${ }^{25}$ Simultaneities between the crime rate and other criminal prosecution indicators are also conceivable. As these are less apparent than in the case of the clearance rate, however, they remain unaccounted for.
} 
performed in growth rates, also lags of order two of endogenous variables (following suggestions in Anderson and Hsiao, 1981, and Arellano and Bond, 1981) are included as instruments.

Table 7: IV Results: Property crimes / violent crimes

\begin{tabular}{|c|c|c|c|c|}
\hline Explanatory Variables & $\begin{array}{c}\text { Property I } \\
\text { (1) }\end{array}$ & $\begin{array}{l}\text { Property II } \\
\text { (2) }\end{array}$ & $\begin{array}{l}\text { Violent I } \\
\text { (3) }\end{array}$ & $\begin{array}{c}\text { Violent II } \\
\text { (4) }\end{array}$ \\
\hline Clearance rate, $p_{c l}$ & $\begin{array}{c}-0.454^{*} \\
(0.219)\end{array}$ & $\begin{array}{c}-0.222 \\
(0.244)\end{array}$ & $\begin{array}{l}-0.119 \\
(0.588)\end{array}$ & $\begin{array}{l}-0.240 \\
(0.811)\end{array}$ \\
\hline Conviction rate, $p_{c v \mid c l}$ & $\begin{array}{c}-0.293 * * \\
(0.035)\end{array}$ & $\begin{array}{c}-0.222 * * \\
(0.035)\end{array}$ & $\begin{array}{c}-0.262 * * \\
(0.018)\end{array}$ & $\begin{array}{c}-0.253^{* *} \\
(0.020)\end{array}$ \\
\hline Imprisonment rate, $p_{s \mid c}$ & $\begin{array}{c}-0.106^{* *} \\
(0.021)\end{array}$ & $\begin{array}{c}-0.059 * * \\
(0.017)\end{array}$ & $\begin{array}{c}0.001 \\
(0.015)\end{array}$ & $\begin{array}{c}0.001 \\
(0.019)\end{array}$ \\
\hline $\ln$ (length of imprisonment), $F$ & $\begin{array}{c}0.030 \\
(0.027)\end{array}$ & $\begin{array}{c}0.018 \\
(0.021)\end{array}$ & $\begin{array}{c}0.024 \\
(0.020)\end{array}$ & $\begin{array}{c}0.027 \\
(0.021)\end{array}$ \\
\hline Per-Capita GDP & $\begin{array}{l}-0.003 \\
(0.190)\end{array}$ & $\begin{array}{c}-0.065 \\
(0.169)\end{array}$ & $\begin{array}{c}-0.444^{*} \\
(0.205)\end{array}$ & $\begin{array}{c}-0.292 \\
(0.268)\end{array}$ \\
\hline Unemployment rate & $\begin{array}{c}0.166^{* *} \\
(0.033)\end{array}$ & $\begin{array}{c}0.112 \\
(0.059)\end{array}$ & $\begin{array}{l}-0.014 \\
(0.032)\end{array}$ & $\begin{array}{l}-0.039 \\
(0.091)\end{array}$ \\
\hline Rate of migrants & $\begin{array}{c}0.304^{* *} \\
(0.259)\end{array}$ & $\begin{array}{c}-0.061 \\
(0.116)\end{array}$ & $\begin{array}{l}0.207^{*} \\
(0.101)\end{array}$ & $\begin{array}{l}-0.035 \\
(0.177)\end{array}$ \\
\hline Share of young males & $\begin{array}{l}0.291 * \\
(0.120)\end{array}$ & $\begin{array}{c}0.050 \\
(0.264)\end{array}$ & $\begin{array}{c}0.575 * * \\
(0.134)\end{array}$ & $\begin{array}{l}-0.098 \\
(0.407)\end{array}$ \\
\hline Crime-specific state effects? & no & no & no & no \\
\hline Crime-specific period effects? & no & yes** & no & yes* \\
\hline Overall $\mathrm{R}^{2}$ & 0.236 & 0.619 & 0.300 & 0.396 \\
\hline Panel-DW & 2.15 & 2.51 & 2.54 & 2.56 \\
\hline Number of observations & 222 & 222 & 222 & 222 \\
\hline Total pool observations & 888 & 888 & 666 & 666 \\
\hline $\begin{array}{l}\text { Testing overidentification (p- } \\
\text { value) }\end{array}$ & $\begin{array}{l}13.7^{*} \\
(0.018)\end{array}$ & $\begin{array}{c}4.34 \\
(0.504)\end{array}$ & $\begin{array}{c}9.05 \\
(0.107)\end{array}$ & $\begin{array}{c}4.66 \\
(0.459)\end{array}$ \\
\hline
\end{tabular}

Notes: IV-estimation of equation (4.4) under pooled FGLS restrictions (4.5) and (4.6); list of additional common IV: $\log \left(\right.$ clearance rate $\left.t_{t-2}\right), \log \left(\right.$ crime rate $\left._{t-2}\right)$, growth rates of the following three variables: regional public debt, attempt ratio, share of crimes committed in small villages; 2SLS-Ftests (Wooldridge, 2002, p. 99) test 'state effects=no, period effects = yes' against 'state effects=yes, period effects = yes'; test of overidentification is based on $n R_{\varepsilon}^{2}$ with $\mathrm{n}=$ total number of observations; robust cross-section SUR (PCSE) standard errors (d.f. corrected) in parentheses; **), *) denotes significance at the 1 and 5 percent level. 
Results of estimating equation (4.4) using IV are presented in Table 7. As is often the case with IV, parameter estimates on instrumented variables become larger with IV (at least for property crimes), but results become less reliable. When comparing results in Table 7 to corresponding results in columns (2) and (4) of Tables 5 and 6, the probability of detection keeps its significance just for one specification. The interpretation of this significant estimate, however, suffers from some potential invalidity of chosen instruments, as indicated by Sargan's overidentification test. Thus, shown results cast some doubt on the deterrent effect of clearance rates. Unfortunately, however, IV estimations are no panacea for endogeneity problems such that no final conclusion can be drawn.

Parameter estimates on conviction rates, imprisonment rates and the severity of prison sentence are almost unaffected. Results confirm that the influence of public prosecutors in combination with convictions in a court is the most important element of the interlinked criminal prosecution process: Lowering convictions rates would increase both property and violent crime rates. This does not unanimously hold for the severity of sanctions. Unconditional imprisonment (instead of suspended custodial sentence or fines) only deters property crime, whereas there is no significant effect on violent crimes. The length of imprisonment does not play any role at all.

Some interesting differences between estimates with and without period effects are worth being considered. Significance of F-Tests (based on second-stage and 2SLS squared residuals, see Wooldridge, 2002, p. 99) indicates unobserved heterogeneity of category-specific time series of growth rates. Included period effects have the intended effect of avoiding some potential omitted variable bias stemming, for example, from unobserved trends in ratios of dark figures or changes in delimiting crime categories. However, including $T \times K$ crime specific time dummies may also have the unintended effect of 'explaining' substantial parts of the variance of common time series (based on just $T$ observations) such as unemployment, GDP or migration. Thus, though statistically inferior, results from specifications without fixed or period effects provide some complementary empirical evidence. Columns (1) and (3) (Table 7) suggest that, notwithstanding problems of neglected unobserved heterogeneity, higher wealth (either in terms of higher GDP p.c. or less unemployment) is associated with less crime, whereas the presence of demographic risk groups (young males, citizens with migration background) is found to be a significant factor of both property and violent crimes. 


\section{Conclusions}

This study disentangles the deterrent effect of criminal prosecution by analyzing the relative contribution of its components police, public prosecution and courts. The entire process, from the police investigation till the judge's verdict, is illustrated and econometrically related to major property and violent crime rates.

The results show that a deterrent effect is exerted by the first two stages of the criminal prosecution process, representing the certainty of conviction. Accordingly, a crime reducing impact would be obtained for higher clearance rates, in particular for crimes against property, although IV estimations indicate loss of significance. Clear results, however, are obtained for the 'conviction rate', which represents the degree of 'certainty' that a suspect is brought to court and convicted in a trial. This result confirms theoretical predictions outlined in the model of custodial and non-custodial sentences of the paper. Conversely, for the indicators of the severity of punishment (type and extent of punishment) deterrent effects are less robust. The effect of imprisonment is only significantly negative for violent crimes. For property crimes, however, changing the judgment towards non-custodial sentences does not have any significant positive or negative effect. The same result occurs for the length of prison sentences.

Summarizing findings, an important implication for public policy is the critical examination of costs and benefits of prevailing pre-trial diversion applied by public prosecutors, i.e. of dropping cases for reasons of the so-called expediency principle. Against the background of high social costs of crime in general and currently rising costs due to aggravated assaults in particular (see general trends in Section 3), it is questionable whether this tendency of public prosecution is actually economically and socially expedient. 'General deterrence' is still capable of curbing crime rates, but just by a more rigorous application of existing penal laws rather than by reforms extending the severity of measures. The latter strategy, followed in the U.S., might bear the risk that the prison population increases without any effect of deterrence. Several authors point out that the U.S. criminal policy might be caught within such dynamics (see Raphael and Stoll, 2009). European policy, on its part, should avoid the error of playing down the risk of its own vicious circle of (violent) crime. Cutting back some diversion reforms such as the exaggerated practice of dropping cases for reasons of expediency, for example, might prevent much harsher future measures that would become necessary in response to public pressure when rates of violent crime are going to continue their current upward trend. 


\section{References}

Aebi, M. (2004). Crime Trends in Western Europe from 1990 to 2000. European Journal on Criminal Policy and Research, 10(2-3), 163-186.

Anderson, T. W., and C. Hsiao (1981). Estimation of Dynamic Models with Error Components. Journal of the American Statistical Association, 76(375), 598-606.

Arellano, M., and S. Bond (1991). Some Tests of Specification for Panel Data: Monte Carlo Evidence and an Application to Employment Data. Review of Economic Studies, 58(2), 277-297.

Baltagi, B.H. (2006). Estimating an Economic Model of Crime Using Panel Data from North Carolina, Replication Study. Journal of Applied Econometrics, 21(4), 543-547.

Bhargava, P., L. Franzini, and W. Narendranathan (1982). Serial correlation and fixed effects models, Review of Economic Studies, 49, 129-140.

Bayer, P., R. Hjalmarsson and D. Pozen (2009). Building Criminal Capital Behind Bars: Peer Effects in Juvenile Corrections. Quarterly Journal of Economics, 124(1), 105-147.

Beck, N., and J.N.Katz (1995). What To Do (And What Not To Do) With Time-Series Cross- Secton Data. American Political Science Review, 89(3), 634-647.

Bentham, J. (1781). An Introduction to the Principles of Morals and Legislation. Batoche Books, Kitchener 2000, http://socserv.mcmaster.ca/econ/ugcm/3ll3/bentham/morals.pdf, (13 April 2011).

Block, M.K. and J.M. Heinecke (1975). A Labor Theoretic Analysis of the Criminal Choice. American Economic Review, 65(3), 314-325.

Bundeskriminalamt [BKA] (2004). Polizeiliche Kriminalstatistik 2003. Wiesbaden.

Bundeskriminalamt [BKA] (2010). Polizeiliche Kriminalstatistik 2009. Wiesbaden.

Busch, T. (2005). Die deutsche Strafrechtsreform. Ein Rückblick auf die sechs Reformen des deutschen Strafrechts (1969 - 1998). Kieler Rechtswissenschaftliche Abhandlungen (NF), Band 47, Baden-Baden: Nomos-Verlag.

Carr-Hill, R.A. and N.H. Stern (1973). An Econometric Model of the Supply and Control of Recorded Offenses in England and Wales. Journal of Public Economics, 2(4), 289-318.

Chen, M.K. and J.M. Shapiro (2007). Does Prison Harden Inmates? A Discontinuity-based Approach. American Law and Economics Review, 9(1), 1-29.

Cornwell, C. and W. N. Trumbull (1994). Estimating the Economic Model of Crime with Panel Data. Review of Economics and Statistics, 76(2), 360-366.

Deaton, A. (2010). Instruments, Randomization and Learning about Development, Journal of Economic Literature, 48(2), 424-455.

Doelling, D., H. Entorf, D. Hermann, and T. Rupp (2009). Is Deterrence Effective? Results of a MetaAnalysis of Punishment, European Journal on Criminal Policy and Research, 15(1-2), 201-224.

Donohue, J. (2009). Assessing the Relative Benefits of Incarceration: The Overall Change Over the Previous Decades and the Benefits on the Margin.” In S. Raphael and M. Stoll (Eds.): Do Prisons Make Us Safer? The Benefits and Costs of the Prison Boom. New York: Russell Sage Foundation Publications.

Durbin, J. (1960). Estimation of Parameters in Time-Series Regression Models, Journal of the Royal Statistical Society, Series B, 22(1), 799-808.

Ehrlich, I. (1973). Participation in Illegitimate Activities: A Theoretical and Empirical Investigation. Journal of Political Economy, 81(3), 521-565. 
Entorf, H. (1997). Random Walks with Drifts: Nonsense Regression and Spurious Fixed-Effect Estimation. Journal of Econometrics, 80(2), 287-296.

Entorf, H. and H. Spengler (2000). Socioeconomic and Demographic Factors of Crime in Germany: Evidence from Panel Data of the German States. International Review of Law and Economics, 20 (1), 75-106.

Entorf, H. and P. Winker (2008). Investigating the Drugs-Crime Channel in Economics of Crime Models: Evidence from Panel Data of the German States. International Review of Law and Economics, 28(1), 8-22.

Funk, P. (2004). On the effective use of stigma as a crime-deterrent. European Economic Review, 48(4), 715-728.

GESIS (2007). The German System of Social Indicators: Key Indicators 1950-2005. Key Public Safety and Crime. http://www.gesis.org/fileadmin/upload/dienstleistung/daten/soz_indikatoren/ Schluesselindikatoren_en/keyindicators.pdf?download=true (13 April 2011).

Grogger, J. (1998). Market Wages and Youth Crime. Journal of Labor Economics, 16(4), 756-791.

Heckman, J.J. (2000). Causal Parameters and Policy Analysis in Economics: A Twentieth Century Retrospective. Quarterly Journal of Economics, 115(1), 45-97.

Heiskanen, M. (2010). Trends in Police-Recorded Crime, in: S. Harrendorf, M. Heiskanen and S. Malby (eds.): International Statistics on Crime and Justice, European Institute for Crime Prevention and Control (HEUNI) and United Nations Office on Drugs and Crime (UNODC), Helsinki, HEUNI Publication Series No. 64.

Heinz, W. (2006). Penal Sanctions and Sanctioning Practice in the Federal Republic of Germany 1882 - 2004. University of Konstanz, The Konstanz Repository of Crime and Sanctioning, http://www.uni-konstanz.de/rtf/kis/sanks04_eng.htm (13 April 2011).

Heinz, W. (2010). Das strafrechtliche Sanktionensystem und die Sanktionspraxis in Deutschland 1882 - 2008. Stand: Berichtsjahr 2008. Version: 1/2010. University of Konstanz. Online publication: http://www.uni-konstanz.de/rtf/kis/Sanktionierungspraxis-in-Deutschland-Stand2008.pdf (13 April 2011).

Imai, S., and K. Krishna (2004). Employment, Dynamic Deterrence and Crime. International Economic Review, 45(3), 845-872.

Kessler, D.P., and A.M. Piehl (1998). The Role of Discretion in the Criminal Justice System. Journal of Law, Economics and Organization, 14(2), 256-276.

LaCasse, C. and A.B. Payne (1999). Federal Sentencing Guidelines and Mandatory Minimum Sentences: Do Defendants Bargain in the Shadow of the Judge? Journal of Law and Economics, 42(1), 245-269.

Levitt, S. D. (1997). Using Electoral Cycles in Police Hiring to Estimate the Effect of Police on Crime. American Economic Review, 87(3), 270-290.

Levitt, S. (2002). Using Electoral Cycles in Police Hiring to Estimate the Effect of Police on Crime: Reply, American Economic Review, 92(4), 1244-1250.

Lin, M.-J. (2008). Does Unemployment Increase Crime? Evidence from U.S. Data 1974 - 2000. Journal of Human Resources 43(2), 413-436.

Mendes, S.M. and M. D. McDonald (2001). Putting Severity Of Punishment Back in the Deterrence Package. Policy Studies Journal, 29(4), 588-610.

Mustard, D.B. (2003). Reexamining Criminal Behavior: The Importance of Omitted Variable Bias. The Review of Economics and Statistics, 85(1), 205-211.

PCS [Bundeskriminalamt] (various issues). Polizeiliche Kriminalstatistik (Police Crime Statistics), Wiesbaden. 
Raphael, S., and R. Winter-Ebmer (2001). Identifying the Effect of Unemployment on Crime. Journal of Law and Economics, 44(1), 259-283.

Raphael, S., and M. Stoll (2009). Why are so many Americans in prison? In: S. Raphael and M. Stoll (Eds.): Do prisons make us safer? The benefits and costs of the prison boom, 27-72. New York: Russell Sage Foundation.

Rasmussen E. (1996). Stigma and Self-Fulfilling Expectations of Criminality. Journal of Law and Economics, 39(2), 519-543.

Reed, W.R. and Ye, H. (2009). Which Panel Data Estimator Should I Use? Applied Economics, 43(8), $1-16$.

Sjoquist, D. L. (1973). Property crime and economic behavior: Some empirical results. American Economic Review, 63(3), 439-446.

Spelman, W. (2008). Specifying the Relationship Between Crime and Imprisonment. Journal of Quantitative Criminology, 24(2), 149-178.

Spengler, H. (2004). Ursachen und Kosten der Kriminalität in Deutschland - drei empirische Untersuchungen [Doctoral Dissertation]. Downloadable: http://elib.tu-darmstadt.de/diss/000531/.

Spengler, H. (2006). Eine panelökonometrische Überprüfung der ökonomischen Theorie der Kriminalität mit deutschen Bundesländerdaten. Journal of Economics and Statistics, 226(6), 687714.

Statistisches Bundesamt (2006). Bevölkerung bis 2050: $11 . \quad$ koordinierte Bevölkerungsvorausberechnung, Wiesbaden: Statistisches Bundesamt.

StVStat [Statistisches Bundesamt] (various issues). Strafverfolgungsstatistik (Criminal Prosecution Statistics), Wiesbaden: Statistisches Bundesamt.

Van Tulder, F. and A. Van der Torre (1999). Modeling Crime and the Law Enforcement System. International Review of Law and Economics, 19(4), 471-486.

Walmsley, R. (2009). World Prison Population List, 8th edn. King's College London.

Weigend, T. (1995). In Germany, Fines Often Imposed In Lieu of Prosecution, in: M.H. Tonry and K. Hamilton (Eds.): Intermediate Sanctions in Overcrowded Times. New York: Oxford University Press, 50-55.

Witte, A.D. (1980). Estimating the Economic Model of Crime with Individual Data. Quarterly Journal of Economics, 94(1), 57-84.

Wolpin, K. I. (1978). An Economic Analysis of Crime and Punishment in England and Wales, 18941967. Journal of Political Economy, 86(5), 815-840.

Wolpin, K. I. (1980). A Time Series-Cross Section Analysis of International Variation in Crime and Punishment. Review of Economics and Statistics, 62(3), 417-423.

Wooldridge, J. M. (2002). Econometric Analysis of Cross Section and Panel Data. Cambridge, MA: The MIT Press.

Zhang, J. (1997). The Effect of Welfare Programs on Criminal Behavior: A Theoretical and Empirical Analysis. Economic Inquiry, 35(1), 120-137. 


\section{Appendix}

Table A1: Descriptive Statistics

\begin{tabular}{|c|c|c|c|c|c|}
\hline Variable & Mean & Median & Std. Dev. & Max & Min \\
\hline $\begin{array}{l}\text { Property crime rates: } \\
\text { - Robbery } \\
\text { - Petty theft } \\
\text { - Serious theft } \\
\text { - Fraud }\end{array}$ & $\begin{array}{c}75.1 \\
2108.4 \\
2557.3 \\
1138.6\end{array}$ & $\begin{array}{c}49.0 \\
1717.6 \\
2190.1 \\
902.8\end{array}$ & $\begin{array}{c}60.5 \\
853.8 \\
1655.2 \\
691.9\end{array}$ & $\begin{array}{c}331.1 \\
4816.0 \\
8314.6 \\
5162.8\end{array}$ & $\begin{array}{c}16.7 \\
1034.3 \\
566.9 \\
330.1\end{array}$ \\
\hline $\begin{array}{l}\text { Violent crime rates: } \\
\text { - Murder, manslaughter } \\
\text { - Rape and indecent assault } \\
\text { - Aggravated assault }\end{array}$ & $\begin{array}{c}7.3 \\
25.2 \\
163.9\end{array}$ & $\begin{array}{c}6.8 \\
21.3 \\
132.4\end{array}$ & $\begin{array}{c}3.1 \\
10.2 \\
82.4\end{array}$ & $\begin{array}{c}23.6 \\
52.2 \\
501.3\end{array}$ & $\begin{array}{c}2.5 \\
10.5 \\
82.9\end{array}$ \\
\hline $\begin{array}{l}\text { Clearance rates: } \\
\text { - Robbery } \\
\text { - Petty theft } \\
\text { - Serious theft } \\
\text { - Fraud } \\
\text { - Murder, manslaughter } \\
\text { - Rape and indecent assault } \\
\text { - Aggravated assault }\end{array}$ & $\begin{array}{l}0.486 \\
0.469 \\
0.152 \\
0.881 \\
0.939 \\
0.676 \\
0.829\end{array}$ & $\begin{array}{l}0.499 \\
0.475 \\
0.152 \\
0.893 \\
0.949 \\
0.675 \\
0.844\end{array}$ & $\begin{array}{l}0.077 \\
0.055 \\
0.048 \\
0.076 \\
0.052 \\
0.069 \\
0.058\end{array}$ & $\begin{array}{l}0.651 \\
0.587 \\
0.281 \\
1.000 \\
1.000 \\
0.846 \\
0.934\end{array}$ & $\begin{array}{l}0.290 \\
0.327 \\
0.062 \\
0.672 \\
0.519 \\
0.469 \\
0.670\end{array}$ \\
\hline $\begin{array}{l}\text { Sentencing rates: } \\
\text { - Robbery } \\
\text { - Petty theft } \\
\text { - Serious theft } \\
\text { - Fraud } \\
\text { - Murder, manslaughter } \\
\text { - Rape and indecent assault } \\
\text { - Aggravated assault }\end{array}$ & $\begin{array}{l}0.291 \\
0.370 \\
0.335 \\
0.305 \\
0.261 \\
0.265 \\
0.176\end{array}$ & $\begin{array}{l}0.295 \\
0.368 \\
0.314 \\
0.313 \\
0.250 \\
0.261 \\
0.173\end{array}$ & $\begin{array}{l}0.059 \\
0.077 \\
0.092 \\
0.068 \\
0.106 \\
0.071 \\
0.035\end{array}$ & $\begin{array}{l}0.509 \\
0.614 \\
0.808 \\
0.468 \\
0.833 \\
0.600 \\
0.292\end{array}$ & $\begin{array}{l}0.121 \\
0.199 \\
0.187 \\
0.098 \\
0.038 \\
0.104 \\
0.102\end{array}$ \\
\hline $\begin{array}{l}\text { Imprisonment rates: } \\
\text { - Robbery } \\
\text { - Petty theft } \\
\text { - Serious theft } \\
\text { - Fraud } \\
\text { - Murder, manslaughter } \\
\text { - Rape and indecent assault } \\
\text { - Aggravated assault }\end{array}$ & $\begin{array}{l}0.626 \\
0.053 \\
0.350 \\
0.056 \\
0.908 \\
0.547 \\
0.108 \\
\end{array}$ & $\begin{array}{l}0.631 \\
0.052 \\
0.345 \\
0.051 \\
0.914 \\
0.545 \\
0.106\end{array}$ & $\begin{array}{l}0.083 \\
0.017 \\
0.063 \\
0.027 \\
0.064 \\
0.080 \\
0.031\end{array}$ & $\begin{array}{l}0.802 \\
0.113 \\
0.534 \\
0.156 \\
1.000 \\
0.767 \\
0.263 \\
\end{array}$ & $\begin{array}{l}0.346 \\
0.019 \\
0.197 \\
0.009 \\
0.667 \\
0.235 \\
0.017 \\
\end{array}$ \\
\hline $\begin{array}{l}\text { Length of prison sentences: } \\
\text { - Robbery } \\
\text { - Petty theft } \\
\text { - Serious theft } \\
\text { - Fraud } \\
\text { - Murder, manslaughter } \\
\text { - Rape and indecent assault } \\
\text { - Aggravated assault }\end{array}$ & $\begin{array}{c}41.80 \\
6.79 \\
15.48 \\
13.75 \\
92.72 \\
39.29 \\
15.04\end{array}$ & $\begin{array}{c}42.27 \\
6.65 \\
15.38 \\
13.47 \\
92.27 \\
39.04 \\
14.90\end{array}$ & $\begin{array}{l}6.13 \\
1.21 \\
1.81 \\
2.58 \\
13.6 \\
7.43 \\
3.02\end{array}$ & $\begin{array}{l}61.35 \\
10.81 \\
21.90 \\
26.61 \\
142.5 \\
79.00 \\
24.33\end{array}$ & $\begin{array}{l}22.6 \\
4.08 \\
10.8 \\
8.55 \\
48.0 \\
23.2 \\
5.25\end{array}$ \\
\hline $\begin{array}{l}\text { Socioeconomic variables: } \\
\text { - Unemployment } \\
\text { - Share of young males, [15, 24] } \\
\text { - Share of migrants } \\
\text { - GDP p.c. (DM, prices of 1995) } \\
\text { - Debt p.c. (DM, prices of 1995) }\end{array}$ & $\begin{array}{c}0.086 \\
0.069 \\
0.081 \\
22,829 \\
3,873\end{array}$ & $\begin{array}{c}0.083 \\
0.069 \\
0.078 \\
21,437 \\
3,131\end{array}$ & $\begin{array}{c}0.034 \\
0.013 \\
0.033 \\
5,691.9 \\
2,774\end{array}$ & $\begin{array}{c}0.189 \\
0.091 \\
0.176 \\
41,135 \\
13,107\end{array}$ & $\begin{array}{c}0.021 \\
0.051 \\
0.029 \\
13,106 \\
479,7\end{array}$ \\
\hline
\end{tabular}

Notes: Descriptive statistics refer to all West German states except Berlin; Sample period: $1977-2001$. Data sources: BKA (PKS, 'Polizeiliche Kriminalstatistik, various issues); Statistisches Bundesamt ('Strafverfolgungsstatistiken', various issues). See Spengler (2004) for a detailed description of merging police statistics and criminal prosecution statistics. 
Table A2: Property crimes (robbery, serious theft, petty theft, fraud); residuals adjusted for serial correlation

\begin{tabular}{|c|c|c|c|c|c|}
\hline Explanatory Variables & (1) & (2) & (3) & (4) & (5) \\
\hline Clearance rate, $p_{c l}$ & $\begin{array}{c}-0.156^{* *} \\
(0.038)\end{array}$ & $\begin{array}{c}-0.168 * * \\
(0.038)\end{array}$ & $\begin{array}{c}-0.289 * * \\
(0.047)\end{array}$ & $\begin{array}{c}-0.292^{* *} \\
(0.046)\end{array}$ & $\begin{array}{l}-0.067 \\
(0.041)\end{array}$ \\
\hline Conviction rate, $p_{c v \mid c l}$ & $\begin{array}{c}-0.214^{* *} \\
(0.021)\end{array}$ & $\begin{array}{c}-0.214^{* *} \\
(0.021)\end{array}$ & $\begin{array}{c}-0.279 * * \\
(0.024)\end{array}$ & $\begin{array}{c}-0.277^{* *} \\
(0.024)\end{array}$ & - \\
\hline Imprisonment rate, $p_{s \mid c}$ & $\begin{array}{c}-0.064^{* *} \\
(0.018)\end{array}$ & $\begin{array}{c}-0.061^{* *} \\
(0.017)\end{array}$ & $\begin{array}{c}-0.111^{* *} \\
(0.021)\end{array}$ & $\begin{array}{c}-0.108 * * \\
(0.021)\end{array}$ & - \\
\hline ln(length of imprisonment), $F$ & $\begin{array}{c}0.041 \\
(0.023)\end{array}$ & $\begin{array}{c}0.033 \\
(0.022)\end{array}$ & $\begin{array}{c}0.029 \\
(0.027)\end{array}$ & $\begin{array}{c}0.026 \\
(0.026)\end{array}$ & $\begin{array}{c}0.001 \\
(0.024)\end{array}$ \\
\hline Per-Capita GDP & $\begin{array}{l}-0.129 \\
(0.162)\end{array}$ & $\begin{array}{l}-0.167 \\
(0.157)\end{array}$ & $\begin{array}{l}-0.017 \\
(0.188)\end{array}$ & $\begin{array}{l}-0.025 \\
(0.182)\end{array}$ & $\begin{array}{l}-0.260 \\
(0.175)\end{array}$ \\
\hline Unemployment rate & $\begin{array}{c}0.098 \\
(0.051)\end{array}$ & $\begin{array}{l}0.098 * \\
(0.050)\end{array}$ & $\begin{array}{l}0.154^{* *} \\
(0.028)\end{array}$ & $\begin{array}{c}0.154^{* *} \\
(0.028)\end{array}$ & $\begin{array}{c}0.101 \\
(0.056)\end{array}$ \\
\hline Rate of migrants & $\begin{array}{l}-0.109 \\
(0.106)\end{array}$ & $\begin{array}{l}-0.038 \\
(0.099)\end{array}$ & $\begin{array}{c}0.302 * * \\
(0.084)\end{array}$ & $\begin{array}{c}0.309 * * \\
(0.082)\end{array}$ & $\begin{array}{c}0.006 \\
(0.110)\end{array}$ \\
\hline Share of young males & $\begin{array}{c}0.088 \\
(0.247)\end{array}$ & $\begin{array}{c}0.141 \\
(0.228)\end{array}$ & $\begin{array}{c}0.301^{* *} \\
(0.114)\end{array}$ & $\begin{array}{c}0.306^{* *} \\
(0.112)\end{array}$ & $\begin{array}{c}0.159 \\
(0.253)\end{array}$ \\
\hline Crime-specific state effects? & yes $^{\text {a) }}$ & no ${ }^{c)}$ & yes $^{c)}$ & No & no ${ }^{c)}$ \\
\hline Crime-specific period effects? & yes** b) & yes** c) & no ${ }^{c)}$ & No & yes $^{* *}$ c) \\
\hline Overall $\mathrm{R}^{2}$ & 0.645 & 0.633 & 0.255 & 0.249 & 0.573 \\
\hline Estimated rho & $\begin{array}{l}-0.284^{* *} \\
(0.037)\end{array}$ & $\begin{array}{c}-0.263 * * \\
(0.036)\end{array}$ & $\begin{array}{l}-0.057 \\
(0.039)\end{array}$ & $\begin{array}{l}-0.048 \\
(0.038)\end{array}$ & $\begin{array}{c}-0.272 * * \\
(0.036)\end{array}$ \\
\hline Panel-DW & 2.08 & 2.06 & 2.01 & 2.01 & 2.07 \\
\hline Number of observations & 222 & 222 & 222 & 222 & 222 \\
\hline Total pool observations & 888 & 888 & 888 & 888 & 888 \\
\hline
\end{tabular}

Notes: All variables enter as growth rates. Cross-section SUR (PCSE) standard errors (d.f. corrected) in parentheses; $\left.{ }^{* *}\right),{ }^{*}$ ) significant at the 1 and 5 percent level; a) Tested (F-tests) against 'state effects=no, period effects = yes'; b) tested against 'state effects=yes, period effects = no'; c) tested against 'state effects=no, period effects $=$ no'. 
Table A3: Violent crimes (murder/manslaughter, rape and indecent assault, aggravated assault); residuals adjusted for serial correlation

\begin{tabular}{|c|c|c|c|c|c|}
\hline Explanatory Variables & (1) & (2) & (3) & (4) & (5) \\
\hline Clearance rate, $p_{c l}$ & $\begin{array}{c}-0.242 * * \\
(0.090)\end{array}$ & $\begin{array}{c}-0.245^{* *} \\
(0.088)\end{array}$ & $\begin{array}{c}-0.234^{* *} \\
(0.084)\end{array}$ & $\begin{array}{c}-0.233^{* *} \\
(0.083)\end{array}$ & $\begin{array}{c}-0.176 \\
(0.097)\end{array}$ \\
\hline Conviction rate, $p_{c v \mid c l}$ & $\begin{array}{c}-0.240 * * \\
(0.019)\end{array}$ & $\begin{array}{c}-0.241 * * \\
(0.019)\end{array}$ & $\begin{array}{c}-0.257^{* *} \\
(0.018)\end{array}$ & $\begin{array}{c}-0.259 * * \\
(0.018)\end{array}$ & - \\
\hline Imprisonment rate, $p_{s \mid c}$ & $\begin{array}{c}-0.001 \\
(0.015)\end{array}$ & $\begin{array}{c}0.001 \\
(0.015)\end{array}$ & $\begin{array}{c}-0.001 \\
(0.014)\end{array}$ & $\begin{array}{l}-0.001 \\
(0.014)\end{array}$ & - \\
\hline ln(length of imprisonment), $F$ & $\begin{array}{c}0.030 \\
(0.020)\end{array}$ & $\begin{array}{c}0.026 \\
(0.020)\end{array}$ & $\begin{array}{c}0.030 \\
(0.019)\end{array}$ & $\begin{array}{c}0.027 \\
(0.019)\end{array}$ & $\begin{array}{c}0.023 \\
(0.023)\end{array}$ \\
\hline Per-Capita GDP & $\begin{array}{c}-0.404 \\
(0.253)\end{array}$ & $\begin{array}{c}-0.447 \\
(0.241)\end{array}$ & $\begin{array}{c}-0.649 * * \\
(0.201)\end{array}$ & $\begin{array}{c}-0.638 * * \\
(0.194)\end{array}$ & $\begin{array}{c}-0.327 \\
(0.269)\end{array}$ \\
\hline Unemployment rate & $\begin{array}{c}-0.038 \\
(0.079)\end{array}$ & $\begin{array}{l}-0.049 \\
(0.076)\end{array}$ & $\begin{array}{l}-0.028 \\
(0.028)\end{array}$ & $\begin{array}{l}-0.029 \\
(0.028)\end{array}$ & $\begin{array}{c}-0.076 \\
(0.084)\end{array}$ \\
\hline Rate of migrants & $\begin{array}{c}-0.095 \\
(0.164)\end{array}$ & $\begin{array}{c}-0.040 \\
(0.150)\end{array}$ & $\begin{array}{c}0.226 * * \\
(0.081)\end{array}$ & $\begin{array}{c}0.227^{* *} \\
(0.078)\end{array}$ & $\begin{array}{c}-0.088 \\
(0.166)\end{array}$ \\
\hline Share of young males & $\begin{array}{c}0.139 \\
(0.164)\end{array}$ & $\begin{array}{c}0.081 \\
(0.345)\end{array}$ & $\begin{array}{c}0.598 * * \\
(0.106)\end{array}$ & $\begin{array}{c}0.590 * * \\
(0.104)\end{array}$ & $\begin{array}{c}0.043 \\
(0.383)\end{array}$ \\
\hline Crime-specific state effects? & yes $^{\text {a) }}$ & no ${ }^{c)}$ & yes ${ }^{c)}$ & no & no ${ }^{c)}$ \\
\hline Crime-specific period effects? & yes*b) & yes* c) & no ${ }^{c)}$ & no & yes**c) \\
\hline Overall $\mathrm{R}^{2}$ & 0.459 & 0.447 & 0.364 & 0.352 & 0.291 \\
\hline Estimated rho & $\begin{array}{c}-0.301 * * \\
(0.041)\end{array}$ & $\begin{array}{c}-0.292^{* *} \\
(0.040)\end{array}$ & $\begin{array}{c}-0.277^{* *} \\
(0.039)\end{array}$ & $\begin{array}{c}-0.269 * * \\
(0.038)\end{array}$ & $\begin{array}{c}-0.337 * * \\
(0.040)\end{array}$ \\
\hline Panel-DW & 2.13 & 2.10 & 2.13 & 2.11 & 2.03 \\
\hline Number of observations & 222 & 222 & 222 & 222 & 222 \\
\hline Total pool observations & 666 & 666 & 666 & 666 & 666 \\
\hline
\end{tabular}

Notes: All variables enter as growth rates. Cross-section SUR (PCSE) standard errors (d.f. corrected) in parentheses; **), *) significant at the 1 and 5 percent level; a) Tested (F-tests) against 'state effects=no, period effects = yes'; b) tested against 'state effects=yes, period effects = no'; c) tested against 'state effects=no, period effects $=$ no' . 
Table A4: Property crimes, estimation of individual crime categories

\begin{tabular}{|c|c|c|c|c|}
\hline Explanatory Variables & Robbery & Petty theft & Serious theft & Fraud \\
\hline Clearance rate, $p_{c l}$ & $\begin{array}{l}-0.138 \\
(0.098)\end{array}$ & $\begin{array}{c}0.039 \\
(0.097)\end{array}$ & $\begin{array}{c}-0.233 * * \\
(0.044)\end{array}$ & $\begin{array}{c}0.235 \\
(0.195)\end{array}$ \\
\hline Conviction rate, $p_{c v \mid c l}$ & $\begin{array}{c}-0.166^{* *} \\
(0.035)\end{array}$ & $\begin{array}{c}-0.198 * * \\
(0.035)\end{array}$ & $\begin{array}{c}-0.320 * * \\
(0.042)\end{array}$ & $\begin{array}{c}-0.275^{* *} \\
(0.068)\end{array}$ \\
\hline Imprisonment rate, $p_{s \mid c}$ & $\begin{array}{c}0.046 \\
(0.051)\end{array}$ & $\begin{array}{c}-0.073^{* *} \\
(0.022)\end{array}$ & $\begin{array}{c}-0.073 \\
(0.056)\end{array}$ & $\begin{array}{c}-0.096 * \\
(0.041)\end{array}$ \\
\hline ln(length of imprisonment), $F$ & $\begin{array}{c}0.110 * \\
(0.043)\end{array}$ & $\begin{array}{c}-0.023 \\
(0.031)\end{array}$ & $\begin{array}{c}0.014 \\
(0.064)\end{array}$ & $\begin{array}{c}0.001 \\
(0.049)\end{array}$ \\
\hline Per-Capita GDP & $\begin{array}{l}-0.530 \\
(0.312)\end{array}$ & $\begin{array}{c}0.077 \\
(0.189)\end{array}$ & $\begin{array}{c}-0.444 \\
(0.269)\end{array}$ & $\begin{array}{l}-0.214 \\
(0.249)\end{array}$ \\
\hline Unemployment rate & $\begin{array}{c}0.004 \\
(0.097)\end{array}$ & $\begin{array}{c}0.063 \\
(0.065)\end{array}$ & $\begin{array}{c}0.232 * * \\
(0.091)\end{array}$ & $\begin{array}{c}0.103 \\
(0.124)\end{array}$ \\
\hline Rate of migrants & $\begin{array}{c}0.346 \\
(0.194)\end{array}$ & $\begin{array}{c}-0.209 \\
(0.126)\end{array}$ & $\begin{array}{c}-0.142 \\
(0.178)\end{array}$ & $\begin{array}{l}-0.109 \\
(0.249)\end{array}$ \\
\hline Share of young males & $\begin{array}{c}0.155 \\
(0.444)\end{array}$ & $\begin{array}{c}0.162 \\
(0.292)\end{array}$ & $\begin{array}{c}0.264 \\
(0.413)\end{array}$ & $\begin{array}{l}-0.171 \\
(0.565)\end{array}$ \\
\hline Crime-specific state effects? & no & no & no & no \\
\hline Crime-specific period effects? & yes** & yes** & yes** & yes** \\
\hline Overall $\mathrm{R}^{2}$ & 0.619 & 0.703 & 0.751 & 0.443 \\
\hline Estimated rho & $\begin{array}{c}-0.326^{* *} \\
(0.070)\end{array}$ & $\begin{array}{c}-0.105 \\
(0.073)\end{array}$ & $\begin{array}{c}-0.118 \\
(0.064)\end{array}$ & $\begin{array}{c}-0.517^{* *} \\
(0.066)\end{array}$ \\
\hline Panel-DW & 2.02 & 2.06 & 2.15 & 2.05 \\
\hline Number of observations & 222 & 222 & 222 & 222 \\
\hline
\end{tabular}

Notes: All variables enter regressions as growth rates. Newey-West HAC standard errors in parentheses; ${ }^{* *}$ ), *) significance at the 1 or 5 percent level, respectively. 
Table A5: Violent crimes, estimation of individual categories

\begin{tabular}{|c|c|c|c|}
\hline Explanatory Variables & $\begin{array}{c}\text { Murder/ } \\
\text { manslaugter }\end{array}$ & $\begin{array}{l}\text { Rape and indecent } \\
\text { assault }\end{array}$ & $\begin{array}{l}\text { Aggravated } \\
\text { assault }\end{array}$ \\
\hline Clearance rate, $p_{c l}$ & $\begin{array}{l}-0.416 \\
(0.273)\end{array}$ & $\begin{array}{l}-0.213^{*} \\
(0.106)\end{array}$ & $\begin{array}{l}-0.118 \\
(0.248)\end{array}$ \\
\hline Conviction rate, $p_{c v \mid c l}$ & $\begin{array}{c}-0.262^{* *} \\
(0.043)\end{array}$ & $\begin{array}{c}-0.191 * * \\
(0.030)\end{array}$ & $\begin{array}{c}-0.300 * * \\
(0.036)\end{array}$ \\
\hline Imprisonment rate, $p_{s \mid c}$ & $\begin{array}{c}0.217 \\
(0.126)\end{array}$ & $\begin{array}{c}0.031 \\
(0.043)\end{array}$ & $\begin{array}{l}-0.007 \\
(0.015)\end{array}$ \\
\hline $\ln$ (length of imprisonment), $F$ & $\begin{array}{c}0.043 \\
(0.070)\end{array}$ & $\begin{array}{c}0.024 \\
(0.050)\end{array}$ & $\begin{array}{c}0.031 \\
(0.022)\end{array}$ \\
\hline Per-Capita GDP & $\begin{array}{c}-1.814^{* *} \\
(0.680)\end{array}$ & $\begin{array}{l}-0.471 \\
(0.415)\end{array}$ & $\begin{array}{l}-0.168 \\
(0.265)\end{array}$ \\
\hline Unemployment rate & $\begin{array}{c}0.166 \\
(0.213)\end{array}$ & $\begin{array}{c}0.190 \\
(0.126)\end{array}$ & $\begin{array}{c}-0.179 * \\
(0.086)\end{array}$ \\
\hline Rate of migrants & $\begin{array}{c}0.251 \\
(0.421)\end{array}$ & $\begin{array}{l}-0.307 \\
(0.250)\end{array}$ & $\begin{array}{c}0.055 \\
(0.171)\end{array}$ \\
\hline Share of young males & $\begin{array}{c}0.927 \\
(0.963)\end{array}$ & $\begin{array}{c}0.856 \\
(0.569)\end{array}$ & $\begin{array}{l}-0.421 \\
(0.389)\end{array}$ \\
\hline Crime-specific state effects? & no & no & no \\
\hline Crime-specific period effects? & yes & yes* & yes* \\
\hline Overall $\mathrm{R}^{2}$ & 0.471 & 0.490 & 0.469 \\
\hline Estimated rho & $\begin{array}{c}-0.341 * * \\
(0.067)\end{array}$ & $\begin{array}{c}-0.375 * * \\
(0.069)\end{array}$ & $\begin{array}{c}-0.181^{* *} \\
(0.069)\end{array}$ \\
\hline Panel-DW & 2.03 & 2.18 & 2.19 \\
\hline Number of observations & 222 & 222 & 222 \\
\hline
\end{tabular}

Notes: All variables enter regressions as growth rates. Newey-West HAC standard errors in parentheses; **), *) significance at the 1 or 5 percent level, respectively. 
a) Maximize expected utility:

$$
\text { (A1) } \begin{aligned}
E(U) & =p\left(1-p_{s \mid c}\right) U\left[A+L^{b}\left(t_{\ell}\right)+G\left(t_{i}\right)\right]+p p_{s \mid c} U\left[A+G\left(t_{i}\right)-F\left(t_{i}\right)\right] \\
& +(1-p) U\left[A+L\left(t_{\ell}\right)+G\left(t_{i}\right)\right]
\end{aligned}
$$

Thus, three different payoffs need to be distinguished. Define

$$
Y_{1}=A+L\left(t_{\ell}\right)+G\left(t_{i}\right), Y_{2}=A+L^{b}\left(t_{\ell}\right)+G\left(t_{i}\right), Y_{3}=A+G\left(t_{i}\right)-F\left(t_{i}\right)
$$

Using the implicit function theorem, we first define

$$
\begin{aligned}
E_{i}=\frac{\partial E(U)}{\partial t_{i}}=p\left(1-p_{s \mid c}\right) U^{\prime}\left(Y_{1}\right) G^{\prime}\left(t_{i}\right)+p p_{s \mid c} U^{\prime}\left(Y_{2}\right)\left[G^{\prime}\left(t_{i}\right)-F^{\prime}\left(t_{i}\right)\right] \\
+(1-p) U^{\prime}\left(Y_{3}\right) G^{\prime}\left(t_{i}\right)=0
\end{aligned}
$$

The second-order condition is

$$
\begin{aligned}
E_{i i}= & p\left(1-p_{s \mid c}\right) U^{\prime \prime}\left(Y_{1}\right) G^{\prime}\left(t_{i}\right)^{2}+p\left(1-p_{s \mid c}\right) U^{\prime}\left(Y_{1}\right) G^{\prime \prime}\left(t_{i}\right) \\
& +p p_{s \mid c} U^{\prime \prime}\left(Y_{2}\right)\left[G^{\prime}\left(t_{i}\right)-F^{\prime}\left(t_{i}\right)\right]^{2}+p p_{s \mid c} U^{\prime}\left(Y_{2}\right)\left[G^{\prime \prime}\left(t_{i}\right)-F^{\prime \prime}\left(t_{i}\right)\right] \\
& +(1-p) U^{\prime \prime}\left(Y_{3}\right) G^{\prime}\left(t_{i}\right)^{2}+(1-p) U^{\prime}\left(Y_{3}\right) G^{\prime \prime}\left(t_{i}\right)
\end{aligned}
$$

$E_{i i}<0 \Leftrightarrow$ assumptions I to III hold, i.e.

- $U^{\prime \prime}<0$

- $G^{\prime \prime}\left(t_{i}\right)<0$

- $F^{\prime \prime}\left(t_{i}\right)>0$

b) The effect of detection and conviction:

$$
\begin{aligned}
& \frac{\partial t_{i}}{\partial p}=-\frac{\frac{\partial E_{i}}{\partial p}}{\frac{\partial E_{i}}{\partial t_{i}}}=-\frac{\left(1-p_{s \mid c}\right) U^{\prime}\left(Y_{1}\right) G^{\prime}\left(t_{i}\right)+p_{s \mid c} U^{\prime}\left(Y_{2}\right)\left[G^{\prime}\left(t_{i}\right)-F^{\prime}\left(t_{i}\right)\right]-U^{\prime}\left(Y_{3}\right) G^{\prime}\left(t_{i}\right)}{E_{i i}} \\
& \text { (A3) }=-\frac{G^{\prime}\left(t_{i}\right)\left(\left(1-p_{s \mid c}\right) U^{\prime}\left(Y_{1}\right)-U^{\prime}\left(Y_{3}\right)\right)+p_{s \mid c} U^{\prime}\left(Y_{2}\right)\left(G^{\prime}\left(t_{i}\right)-F^{\prime}\left(t_{i}\right)\right)}{E_{i i}}
\end{aligned}
$$




$$
\begin{aligned}
\frac{\partial t_{i}}{\partial p}<0 & \Leftrightarrow \\
& \bullet \quad G^{\prime}\left(t_{i}\right)-F^{\prime}\left(t_{i}\right)<0 \quad \text { (see assumption IV) } \\
& \text { - } \quad Y_{3}-Y_{1}=L\left(t_{\ell}\right)-L^{b}\left(t_{\ell}\right)>0 \Rightarrow\left(1-p_{s \mid c}\right) U^{\prime}\left(Y_{1}\right)-U^{\prime}\left(Y_{3}\right)<0 \\
& \text { (assumption of 'stigma') }
\end{aligned}
$$

c) The effect of non-custodial sentencing:

$$
\begin{gathered}
\frac{\partial t_{i}}{\partial\left(1-p_{s \mid c}\right)}=-\frac{\frac{\partial E_{i}}{\partial\left(1-p_{s \mid c}\right)}}{E_{i i}}=-\frac{p U^{\prime}\left(Y_{1}\right) G^{\prime}\left(t_{i}\right)-p U^{\prime}\left(Y_{2}\right)\left[G^{\prime}\left(t_{i}\right)-F^{\prime}\left(t_{i}\right)\right]}{E_{i i}} \\
=-\frac{(+)-(-)}{(-)}>0
\end{gathered}
$$

Again, the unambiguous sign depends on the validity of Assumption IV.

d) Finally, the crime reducing effect of the gap $L\left(t_{\ell}\right)-L^{b}\left(t_{\ell}\right)$ ('stigma') is obvious from (A1) and from $E_{i i}<0$. 